\title{
Potassium Effects on NCC Are Attenuated during Inhibition of Cullin E3-Ubiquitin Ligases
}

\author{
Sathish K. Murali ${ }^{1,2,3}$, Robert Little ${ }^{1,2}$, Søren B. Poulsen ${ }^{1,2}$, Mohammed Z. Ferdaus ${ }^{2,4}$, David H. Ellison ${ }^{2,4,5}$, \\ James A. McCormick ${ }^{2,4}$ and Robert A. Fenton 1,2,*(D) \\ 1 Department of Biomedicine, Aarhus University, 8000 Aarhus, Denmark; \\ Sathish.Murali@vetmeduni.ac.at (S.K.M.); r.little@biomed.au.dk (R.L.); sbpo@biomed.au.dk (S.B.P.) \\ 2 Leducq Foundation Potassium in Hypertension International Network, 265 Franklin Street, \\ Boston, MA 02110, USA; mohammed.ferdaus@vumc.org (M.Z.F.); ellisond@ohsu.edu (D.H.E.); \\ mccormij@ohsu.edu (J.A.M.) \\ 3 Department of Biomedical Sciences, University of Veterinary Medicine, 1210 Vienna, Austria \\ 4 Department of Medicine, Oregon Health and Science University, Portland, OR 97239, USA \\ 5 VA Portland Health Care System, Portland, OR 97239, USA \\ * Correspondence: robert.a.fenton@biomed.au.dk
}

check for updates

Citation: Murali, S.K.; Little, R.; Poulsen, S.B.; Ferdaus, M.Z.; Ellison, D.H.; McCormick, J.A.; Fenton, R.A. Potassium Effects on NCC Are Attenuated during Inhibition of Cullin E3-Ubiquitin Ligases. Cells 2022, 11, 95. https://doi.org/ 10.3390/cells11010095

Academic Editors: Hanjo Hellmann and Cord Brakebusch

Received: 29 November 2021 Accepted: 22 December 2021 Published: 29 December 2021

Publisher's Note: MDPI stays neutral with regard to jurisdictional claims in published maps and institutional affiliations.

Copyright: (c) 2021 by the authors. Licensee MDPI, Basel, Switzerland. This article is an open access article distributed under the terms and conditions of the Creative Commons Attribution (CC BY) license (https:// creativecommons.org/licenses/by/ $4.0 /)$.

\begin{abstract}
The thiazide-sensitive sodium chloride cotransporter (NCC) plays a vital role in maintaining sodium $\left(\mathrm{Na}^{+}\right)$and potassium $\left(\mathrm{K}^{+}\right)$homeostasis. NCC activity is modulated by with-no-lysine kinases 1 and 4 (WNK1 and WNK4), the abundance of which is controlled by the RING-type E3 ligase Cullin 3 (Cul3) and its substrate adapter Kelch-like protein 3. Dietary $\mathrm{K}^{+}$intake has an inverse correlation with NCC activity, but the mechanism underlying this phenomenon remains to be fully elucidated. Here, we investigated the involvement of other members of the cullin family in mediating $\mathrm{K}^{+}$effects on NCC phosphorylation (active form) and abundance. In kidneys from mice fed diets varying in $\mathrm{K}^{+}$content, there were negative correlations between NCC (phosphorylated and total) and active (neddylated) forms of cullins (Cul1, 3, 4, and 5). High dietary $\mathrm{K}^{+}$effects on phosphorylated NCC were attenuated in Cul3 mutant mice (CUL3-Het/ $\Delta 9$ ). Short-term (30 $\mathrm{min}$ ) and long-term $(24 \mathrm{~h}$ ) alterations in the extracellular $\mathrm{K}^{+}$concentration did not affect cullin neddylation levels in ex vivo renal tubules. In the short term, the ability of high extracellular $\mathrm{K}^{+}$to decrease NCC phosphorylation was preserved in the presence of MLN4924 (pan-cullin inhibitor), but the response to low extracellular $\mathrm{K}^{+}$was absent. In the long term, MLN4924 attenuated the effects of high extracellular $\mathrm{K}^{+}$on NCC phosphorylation, and responses to low extracellular $\mathrm{K}^{+}$were absent. Our data suggest that in addition to Cul3, other cullins are involved in mediating the effects of $\mathrm{K}^{+}$on NCC phosphorylation and abundance.
\end{abstract}

Keywords: cullins; E3 ligase; NCC; potassium

\section{Introduction}

Hypertension, or high blood pressure (BP), affects more than $20 \%$ of the population and is a major public health problem due to its contribution to stroke, heart failure, and kidney failure [1]. Although sodium $\left(\mathrm{Na}^{+}\right)$-rich diets are major contributors to the onset of hypertension, a low potassium $\left(\mathrm{K}^{+}\right)$intake often accompanies this high $\mathrm{Na}^{+}$intake, and dietary $\mathrm{K}^{+}$intake can have an inverse correlation with BP [2,3]. In the kidney, the thiazide-sensitive sodium chloride cotransporter (NCC) reabsorbs $5-10 \%$ of filtered $\mathrm{Na}^{+}$in the distal convoluted tubules (DCT). As highlighted by patients with Gitelman syndrome (loss-of-function mutations in NCC) and familial hyperkalemic hypertension (FHHt, also known as pseudohypoaldosteronism type II (PHAII)), NCC is essential for maintaining normal BP $[4,5]$. NCC also plays an essential role in the antihypertensive effects of dietary $\mathrm{K}^{+}$, with the effects of a low $\mathrm{K}^{+}$diet on BP absent in NCC knockout mice or mice receiving hydrochlorothiazide (NCC inhibitor) [6,7]. 
Patients with Gitelman syndrome suffer from hypokalemia, while patients with $\mathrm{FHHt}$ suffer from hyperkalemia, demonstrating that NCC is also essential for $\mathrm{K}^{+}$homeostasis $[5,8]$. During hyperkalemia, NCC phosphorylation (active form) and abundance are reduced. This increases $\mathrm{Na}^{+}$delivery to the amiloride-sensitive epithelial sodium channel (ENaC) [9] in downstream segments of the renal tubule, enhancing electrogenic $\mathrm{K}^{+}$secretion via the renal outer medullary potassium channel (ROMK) and flow-dependent large $\mathrm{Ca}^{2+}$ activated $\mathrm{K}^{+}(\mathrm{BK})$ channels to help restore plasma $\mathrm{K}^{+}$levels to normal. Conversely, during hypokalemia NCC phosphorylation and abundance are increased. Although this limits electrogenic $\mathrm{K}^{+}$secretion, the consequence is increased $\mathrm{Na}^{+}$reabsorption, hypervolemia, and increased BP.

Studies in FHHt patients established that mutations in genes encoding for with-nolysine kinases 1 and 4 (WNK1 and WNK4) or the RING-type E3 ligase Cullin 3 (Cul3) and its substrate adapter Kelch-like protein 3 (KLHL3) control the phosphorylation and activation of NCC $[8,10]$. Mutations in WNK1 or WNK4 lead to hyperactivation of the STE20-related proline/alanine-rich kinase (SPAK) and oxidative stress-responsive 1 kinase (OSR1), with SPAK directly phosphorylating and activating NCC. Cul3 and KLHL3 together form an E3 ubiquitin ligase complex that ubiquitylates WNK1/4 kinases, targeting them for degradation. Loss-of-function mutations in Cul3 or KLHL3 prevent their interactions with WNK1/4, limiting the degradation of these kinases and resulting in sustained activation of the WNK-SPAK/OSR1-NCC pathway.

Altered NCC phosphorylation following low or high dietary $\mathrm{K}^{+}$intake is linked to alterations in the basolateral plasma membrane potential via the inwardly rectifying potassium channel Kir 4.1/Kir 5.1 (a heterotetramer of Kir4.1 and Kir5.1 channels) and modulation of the WNK-SPAK/OSR1 kinase signaling pathway [11-15]. However, low $\mathrm{K}^{+}$intake also increases phosphorylation of KLHL3, which impairs Cul3-WNK binding and degradation, resulting in increased NCC [16]. Cul3 is one member of a large class of RING-type E3 ligases (Cul1-5 and Cul7 [17]). Activation of cullins requires neddylation, a post-translational modification in which the ubiquitin-like modifier neuronal precursor cell-expressed developmentally downregulated protein 8 (NEDD8) is covalently attached to the target protein $[18,19]$. Processing of NEDD8 by the NEDD8-activating enzyme (NAE) is a prerequisite for binding of NEDD8 to cullins [20,21]. Conversely, enzymatic removal of NEDD8 from cullins leads to deactivation of the ligase, a process regulated by the COP9 signalosome (CSN), an eight-subunit protein complex with isopeptidase activity. Specifically, the isopeptidase activity of CSN5 (or Jun activation domain-binding protein 1, Jab1) catalyzes the enzymatic removal of NEDD8 from the Cullin E3-ligase complex [22,23].

Using mass spectrometry, we recently discovered that Cul1 is enriched in the DCT, and Cul1 and Cul2 abundances are increased in the DCT of mice fed a high $\mathrm{K}^{+}$diet for 4 days [24]. This suggests that cullins other than $\mathrm{Cul} 3$ may also play a role in mediating the inhibitory effects of $\mathrm{K}^{+}$on NCC phosphorylation and abundance. To investigate this further, here we (1) examined the abundance and neddylation status of cullins in mice fed different $\mathrm{K}^{+}$diets or after incubation of ex vivo cultured renal tubules with $\mathrm{K}^{+}$, (2) examined NCC abundance and phosphorylation in Cul3- $\Delta 9$ mice (a model of FHHt with aberrant Cul3 function [25]) fed a high $\mathrm{K}^{+}$diet, and (3) examined in ex vivo isolated renal tubules the effects of high $\mathrm{K}^{+}$on NCC phosphorylation and abundance during cullin or WNK kinase inhibition. Our data suggest that Cul3 and potentially other cullin family members are involved in the $\mathrm{K}^{+}$-mediated regulation of NCC.

\section{Experimental Procedures}

\subsection{Animal Experiments and Tissue Isolation}

All protocols were approved and performed under a license issued for the use of experimental animals by the Danish Ministry of Justice (Dyreforsøgstilsynet). Male C57Bl/6J mice, 10-12 weeks of age, were kept in standard cages in a room with a 12:12 hr artificial light-dark cycle with free access to tap water and a standard rodent chow (1324 pellets, Altromin, Germany). For experiments involving different $\mathrm{K}^{+}$diets, mice were switched 
to either a control $\left(1 \% \mathrm{~K}^{+}\right)$or a high $5 \% \mathrm{~K}^{+}$diet for 3 weeks, or a $0 \% \mathrm{~K}^{+}$diet for 2 weeks (Teklad Diet, Madison, WI, USA). Diets were prepared from powdered commercial diet free of $\mathrm{Na}^{+}, \mathrm{K}^{+}$, and $\mathrm{Cl}^{-}$(Teklad Diet: TD.08251, Envigo, USA), and appropriate amounts of $\mathrm{NaCl}$ and $\mathrm{KCl}$ were added back to obtain $0 \% \mathrm{~K}^{+}$diet $\left(0.3 \% \mathrm{Na}^{+}, 0.3 \% \mathrm{Cl}^{-}\right.$, and $\left.0 \% \mathrm{~K}^{+}\right)$, $1 \% \mathrm{~K}^{+} \operatorname{diet}\left(0.3 \% \mathrm{Na}^{+}, 0.3 \% \mathrm{Cl}^{-}\right.$, and $\left.1.05 \% \mathrm{~K}^{+}\right)$, and $5 \% \mathrm{~K}^{+} \operatorname{diet}\left(0.3 \% \mathrm{Na}^{+}, 0.3 \% \mathrm{Cl}^{-}\right.$, and $5.25 \% \mathrm{~K}^{+}$). Mice were euthanized by cervical dislocation, followed by harvesting and homogenization of kidneys in ice-cold dissection buffer solution ( $\mathrm{pH}$ 7.6) containing $250 \mathrm{mM}$ sucrose, $10 \mathrm{mM}$ triethanolamine, PhosSTOP, and cOmplete Mini tablets (Roche Diagnostics A/S, Mannheim, Germany). Kidney protein samples were prepared for immunoblotting using Laemmli sample buffer containing $15 \mathrm{mg} / \mathrm{mL}$ DTT.

\subsection{Studies in Cul3-Het/D9 Mice}

Cul3-Het/ $\Delta 9$ mice, a model for FHHt, were generated as described [25]. Studies were approved by the Oregon Health and Science University Institutional Animal Care and Use Committee (protocol IP00286). Males aged 8-12 weeks were administered doxycycline $(2 \mathrm{mg} / \mathrm{mL}$ in $5 \%$ sucrose drinking water) for 2 weeks to induce Cul3-Het/ $\Delta 9$ expression in epithelial cells throughout the renal tubule. Controls were genetically identical but received only $5 \%$ sucrose drinking water. After a 2-week washout period, mice were fed control diet $\left(0.8 \% \mathrm{~K}^{+}\right.$, TD.07309, Envigo) or a matched diet with $5 \% \mathrm{~K}^{+}$(equimolar carbonate/citrate $/ \mathrm{Cl}$ as anions, TD.07278, Envigo) for 7 days. The $\mathrm{NaCl}$ content was $0.32 \%$ in both diets, and water was provided ad libitum. Blood was collected via cardiac puncture under isoflurane anesthesia and transferred into heparinized tubes; $80 \mu \mathrm{L}$ was loaded into a Chem $8^{+}$ cartridge for electrolyte measurement by an i-STAT analyzer (Abbott Point of Care Inc., Princeton, NJ, USA). Kidneys were harvested following blood collection under isoflurane anesthesia, snap-frozen in liquid nitrogen, and stored at $-80{ }^{\circ} \mathrm{C}$ until homogenization. Sample processing and immunoblotting were performed as described [25].

\subsection{Kidney Tubule Suspensions}

Ex vivo mouse kidney tubule preparations were generated as previously described [26]. These preparations contain segments representative of the whole renal tubule, including the DCT. The viability of the isolated renal tubules for the experimental duration was determined previously [27]. Following isolation, tubules were equally divided into individual wells of tissue culture plates for further treatments. For experiments involving varying $\mathrm{K}^{+}$concentrations, isolated tubules were initially incubated at $37^{\circ} \mathrm{C}$ for $2 \mathrm{~h}$ in media containing $3.5 \mathrm{mM} \mathrm{K}^{+}$for acclimatization. After $2 \mathrm{~h}$, media was gently removed and replaced with new media containing either $2.5,3.5$, or $6 \mathrm{mM} \mathrm{K}^{+}$at $37^{\circ} \mathrm{C}$ for $30 \mathrm{~min}$ or $24 \mathrm{~h}$. $\mathrm{K}^{+}$was provided as $\mathrm{KCl}$, and $\mathrm{NaCl}$ was used to balance $\mathrm{Cl}^{-}$concentration in the media. For experiments involving the general cullin inhibitor MLN4924 (BioNordika) and varying $\mathrm{K}^{+}$concentrations, media was gently removed and replaced with new media containing either a vehicle (DMSO) or MLN4924 $(0.5 \mu \mathrm{M})$ for $1 \mathrm{~h}$ at $37^{\circ} \mathrm{C}$. Subsequently, media was removed and replaced with new media containing either $2.5,3.5$, or $6 \mathrm{mM} \mathrm{K}^{+}$ with or without MLN4924 $(0.5 \mu \mathrm{M})$ and tubules incubated at $37^{\circ} \mathrm{C}$ for $30 \mathrm{~min}$ or $24 \mathrm{~h}$. For experiments involving the general WNK inhibitor stock2s (Tocris) and MLN4924, following acclimatization media was gently removed and replaced with new media containing $50 \mu \mathrm{M}$ stock $2 \mathrm{~s}$ for $1 \mathrm{~h}$ at $37^{\circ} \mathrm{C}$. Subsequently, media was removed and replaced with new media containing either the vehicle or stock2s in the presence or absence of MLN4924 at $37^{\circ} \mathrm{C}$ for $2 \mathrm{~h}$. Following all experiments, media was removed, and protein was extracted from the tubules using Laemmli sample buffer containing $15 \mathrm{mg} / \mathrm{mL}$ DTT. Samples were sonicated and denatured at $60^{\circ} \mathrm{C}$ for $15 \mathrm{~min}$.

\subsection{Antibodies and Immunoblotting}

Primary antibodies used in immunoblotting include phosphorylated NCC (pT58) [28], NCC (SPC-402D, StressMarq), pSPAK/OSR1 (07-2273, Millipore), SPAK/OSR1 [29], Cul1 (sc-17775, Santa Cruz), Cul2 (sc-166506, Santa Cruz), Cul3 (sc-166110, Santa Cruz), Cul4 
(sc-377188, Santa Cruz), Cul5 (sc-373822, Santa Cruz), CSN5/Jab1 (sc-13157, Santa Cruz), NAE (sc-390002, Santa Cruz), and Proteasome 20S (ab3325, Abcam). Blotting of samples from Cul3-Het/ $\Delta 9$ mice was performed using $\beta$-actin (ab8227, Abcam), NCC [30], and pT53NCC [30] antibodies. The specificity of the commercial antibodies was based on the fact that either they gave a single unique band on an immunoblot corresponding to the target proteins predicting molecular weight, or the most prominent band on the immunoblot was at the target proteins predicting molecular weight (with no other bands of similar size). The pT58NCC, pT53NCC, and total NCC antibodies have been validated using tissue from NCC knockout mice. Immunoblotting was performed as previously described [26] and for Cul3-Het/ $\Delta 9$ mice [25]. Blots were developed using a SuperSignal West Femto chemiluminescent substrate (Thermo Scientific, Roskilde, Denmark) or Amersham ECL Western Blotting Detection Reagent (GE Healthcare). Band intensity was quantified using Image Studio Lite (Qiagen) densitometry analysis.

\subsection{Statistics}

Data in all graphs are shown as mean \pm SEM. Individual sample size $(n)$ is shown in figure legends. For comparing two groups of data, a Student's unpaired $t$-test was used. For comparisons of more than two groups, one-way or two-way ANOVA, followed by Dunnett's or Tukey's multiple comparison tests, was used. Significance was considered at $p<0.05$.

\section{Results}

\subsection{High Dietary $\mathrm{K}^{+}$Intake Decreases NCC without Major Alterations in Cullin Expression}

Using mass spectrometry, Cul1 and Cul2 expressions were increased in the DCT of mice fed a high $\mathrm{K}^{+}$diet for 4 days [24]. To further examine alterations in cullin expression during high dietary $\mathrm{K}^{+}$intake, mice were fed either a $0 \%, 1 \%$, or $5 \% \mathrm{~K}^{+}$diet for $2-3$ weeks, and the abundance of cullins in whole kidney homogenates was determined using Western blotting. Relative to the $1 \% \mathrm{~K}^{+}$intake, phosphorylation of NCC (pT58) and total NCC abundance were greater in the kidneys from mice receiving a $0 \% \mathrm{~K}^{+}$diet, but lower in those receiving a $5 \% \mathrm{~K}^{+}$diet (Figure 1A,B). No significant differences in the abundances of Cul1, 2, 3, 4, and 5 were observed in whole kidney homogenates from mice under any of the dietary conditions (Figure 1A,B). No significant differences were observed in the abundance of NAE (enzyme responsible for the activation of cullins), whereas CSN5/Jab1 levels (which deactivates cullins) were significantly higher on the $5 \% \mathrm{~K}^{+}$diet relative to the $1 \% \mathrm{~K}^{+} \operatorname{diet}($ Figure $1 \mathrm{~A}, \mathrm{~B})$.

\subsection{Low Dietary $\mathrm{K}^{+}$Intake Is Associated with Decreased Neddylation of Cullins}

Activity of cullins depends on their neddylation status, with cycling between neddylated and deneddylated forms changing the stability of the ligase, with the degree of neddylation having a direct correlation with their activity and ubiquitin-mediated degradation of their target substrates [31-36]. This neddylation status can be observed in the reducing conditions of Western blotting, where cullin proteins are detected as a doublet (Figure 1A), the lower molecular weight band representing the non-neddylated (inactive) form and the higher molecular weight band representing the neddylated (active) form. Here, the ratio of neddylated cullins (n-Cul) to total cullin abundance (Cul) was used to determine the percentage of active cullins. In mice on a $0 \% \mathrm{~K}^{+}$diet, neddylation levels of Cul1, Cul3, Cul4, and Cul5 were significantly lower than those in mice on a $1 \%$ diet (Figure 2A). No significant changes to the neddylation status of Cul2 were observed following dietary manipulation (Figure 2A). Nonlinear regression analysis was applied to correlate the percentage change in pT58NCC and total NCC abundance following dietary $\mathrm{K}^{+}$manipulation with the $\mathrm{n}-\mathrm{Cul} / \mathrm{Cul}$ ratio. A significant negative correlation was detected between pT58NCC or total NCC abundance and the n-Cul/Cul ratio for Cul1, 3, 4 , and 5 (Figure 2B,C). Although there appeared to be a positive correlation between the $\mathrm{n}-\mathrm{Cul2} / \mathrm{Cul} 2$ ratio and NCC, this did not reach significance (Figure 2B,C). 
A

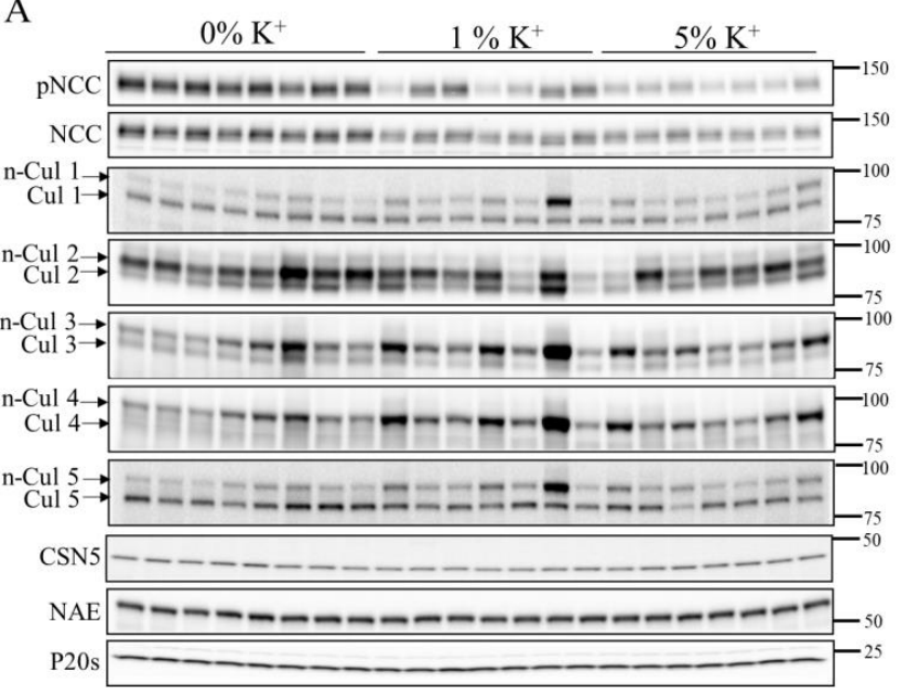

B
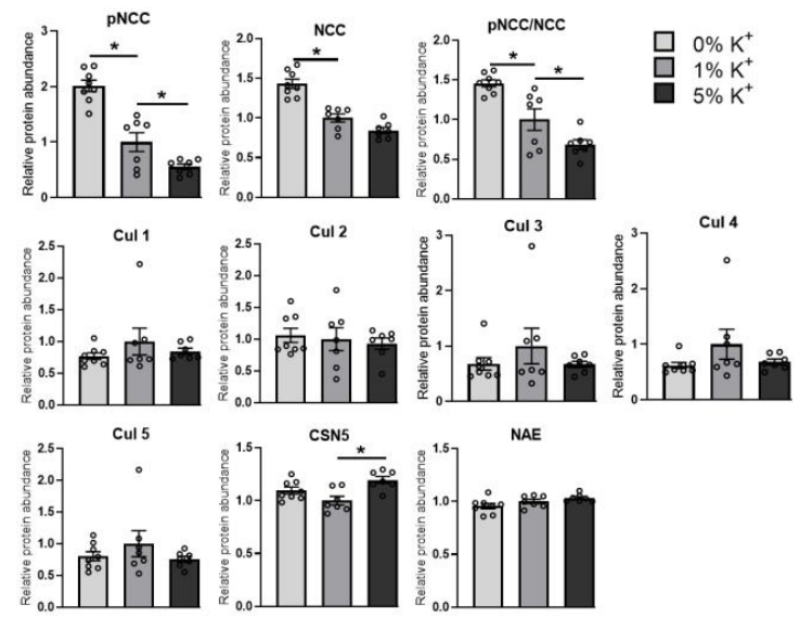

Figure 1. Increase in dietary $\mathrm{K}^{+}$supplementation decreases renal abundance of phosphorylated and total NCC in mice without altering cullin expression. (A) Representative immunoblots of pNCC, NCC, cullins (neddylated: n-Cul and non-neddylated: Cul), CSN5, NAE, and P20s in kidney homogenates of mice placed on a $0 \% \mathrm{~K}^{+}(n=8), 1 \% \mathrm{~K}^{+}(n=7)$, or $5 \% \mathrm{~K}^{+}(n=7)$ diet. Molecular weight markers $(\mathrm{kDa})$ are shown on the right. (B) Summarized relative protein abundance data. Each bar represents mean \pm SEM and each dot represents value from an individual mouse. ${ }^{*}$ indicates $p<0.05$ relative to mice that were on $1 \% \mathrm{~K}^{+}$diet.

A

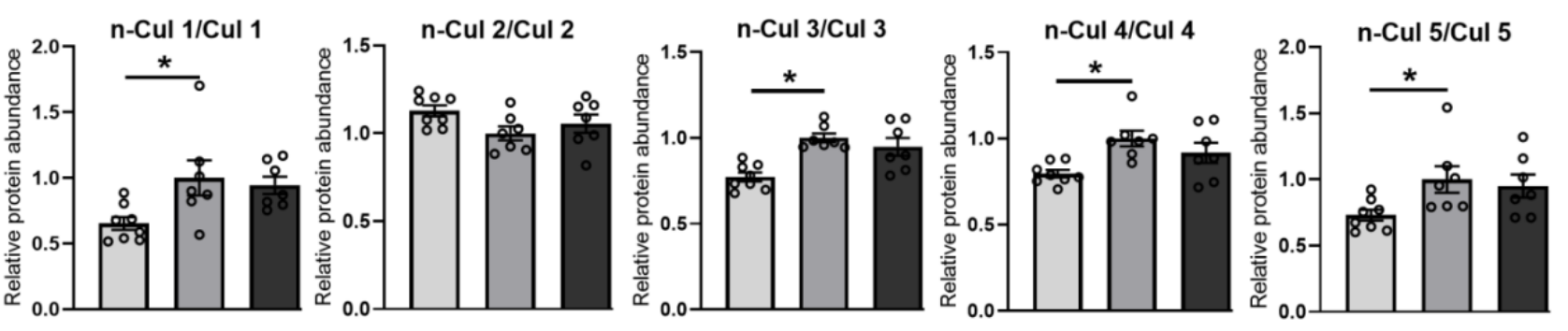

B
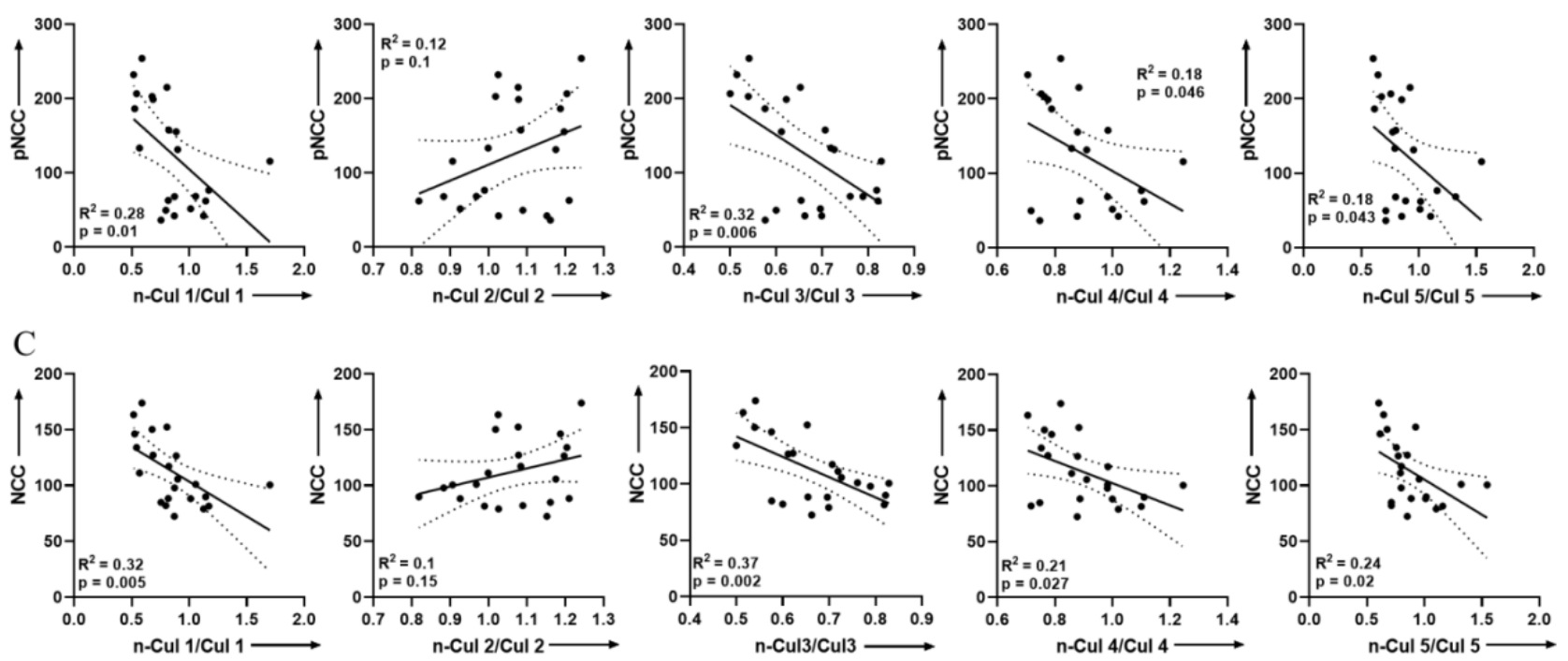

Figure 2. Low dietary $\mathrm{K}^{+}$supplementation decreases neddylation levels of Cul1, 3, 4, and 5. (A) Summary data of relative abundances of neddylated to non-neddylated form of Cul1, 2, 3, 4, and 5 . 
(B) Linear regression analysis of n-Cul/Cul ratio and pNCC in kidneys of mice that were on different $\mathrm{K}^{+}$diets $\left(0 \% \mathrm{~K}^{+}, 1 \% \mathrm{~K}^{+}\right.$, and $\left.5 \% \mathrm{~K}^{+}\right)$. (C) Linear regression analysis of $\mathrm{n}-\mathrm{Cul} / \mathrm{Cul}$ ratio and $\mathrm{NCC}$ in kidneys of mice that were on different $\mathrm{K}^{+}$diets $\left(0 \% \mathrm{~K}^{+}, 1 \% \mathrm{~K}^{+}\right.$, and $\left.5 \% \mathrm{~K}^{+}\right)$. Each bar represents mean \pm SEM. * in panel A indicates $p<0.05$ relative to mice that were on $1 \% \mathrm{~K}^{+}$diet. For all panels each dot represents value from an individual mouse.

\subsection{The Effects of a High Dietary $\mathrm{K}^{+}$Intake on NCC Phosphorylation Are Attenuated in Cul3-Het/ $\Delta 9$ Mice}

The Cul3-KLHL3 complex modulates NCC activity by altering the ubiquitin-mediated degradation of WNK1 and WNK4 kinases [37]. Autosomal dominant mutations in the Cul3 gene cause haploinsufficiency and a severe form of FHHt, most likely a result of rapid Cul3 degradation following autoubiquitination [38]. This is recapitulated in a mouse model, CUL3-Het/ $\Delta 9$ mice, which are characterized by higher levels of WNK kinases and increased SPAK and NCC phosphorylation $[10,25,38,39]$. To investigate whether Cul3 plays a role in mediating the inhibitory effects of high $\mathrm{K}^{+}$on NCC in the long term, CUL3Het $/ \Delta 9$ mice were fed a control or high $5 \% \mathrm{~K}^{+}$diet for 1 week. CUL3-Het $/ \Delta 9$ mice had significantly increased renal expression of phosphorylated pT53NCC $(100 \pm 13.4 \%$ vs. $288.5 \pm 22.5 \%)$ and total NCC abundance (100 $\pm 11.8 \%$ vs. $229.9 \pm 30.8 \%)$ compared with the control animals (Figure $3 \mathrm{~A}, \mathrm{~B}$ ). High dietary $\mathrm{K}^{+}$significantly reduced pT53NCC (100 $\pm 13.4 \%$ vs. $20.5 \pm 3.1 \% ; \sim 80 \%$ reduction) and total NCC abundance (100 $\pm 11.8 \%$ vs. $56.5 \pm 3.2 \% ; \sim 44 \%$ reduction) in control mice (Figure 3A,B). The high $\mathrm{K}^{+}$diet significantly reduced total NCC abundance in CUL3-Het/ $\triangle 9$ mice to a similar extent as observed in control animals ( $229.9 \pm 30.8 \%$ vs. $117.4 \pm 8.9 \% ; ~ 49 \%$ reduction) (Figure $3 \mathrm{~A}, \mathrm{~B})$. However, the reduction in pT53NCC expression in response to the high $\mathrm{K}^{+}$diet in CUL3-Het/ $\Delta 9$ mice, although significant, was not of the same magnitude as that observed in control mice $(288.5 \pm 22.5 \%$ vs. $132.2 \pm 23.5 \%$; $54 \%$ reduction) (Figure $3 \mathrm{~A}, \mathrm{~B})$. Furthermore, the phosphorylated-NCC-to-total-NCC ratio (as an indicator of relative NCC phosphorylation) was only significantly reduced in the control mice receiving a high $\mathrm{K}^{+}$diet and not in CUL3-Het/ $\Delta 9$ mice (Figure $3 \mathrm{~A}, \mathrm{~B})$.

A

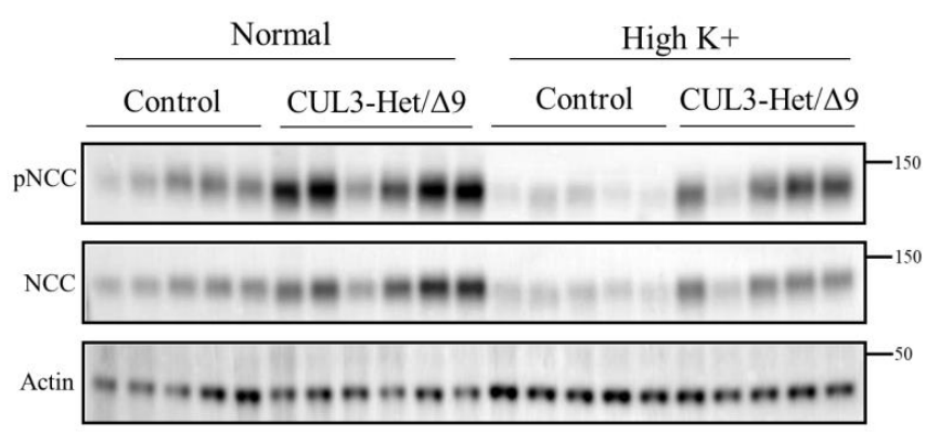

B

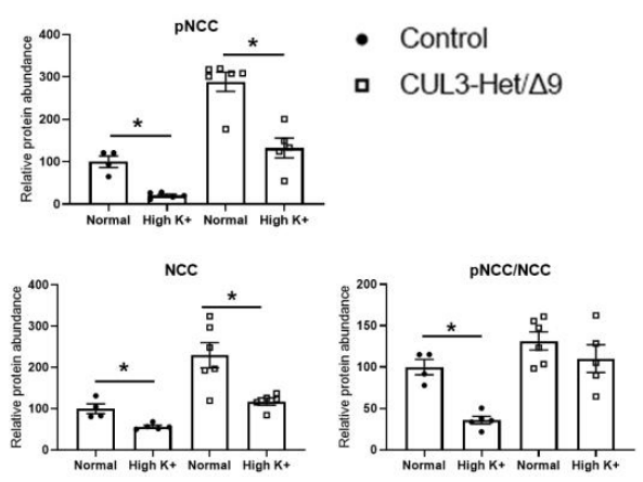

Figure 3. High dietary $\mathrm{K}^{+}$supplementation effects on NCC phosphorylation is attenuated in Cul3- $\Delta 9$ mice. (A) Representative immunoblots of pNCC, NCC, and actin in kidney homogenates of control and Cul3- $\Delta 9$ mice that were on either normal diet (control, $n=5$, vs. Cul3- $\Delta 9, n=6$ ) or high $\mathrm{K}^{+}$ diet (control, $n=5$, vs. Cul3- $\Delta 9, n=5$ ). Molecular weight markers (kDa) are shown on the right. (B) Summarized relative protein abundance data. Each dot represents value from an individual mouse and bars represents mean \pm SEM. * indicates $p<0.05$ relative to mice that were on control diet in their respective group.

\subsection{Extracellular $\mathrm{K}^{+}$Changes NCC Phosphorylation and Abundance in Isolated Ex Vivo Renal Tubules}

Alterations in dietary $\mathrm{K}^{+}$intake can alter levels of aldosterone, renin, and angiotensin II, which may play a role in the modulation of NCC phosphorylation and abundance [40-42]. 
Altered plasma $\mathrm{K}^{+}$levels per se observed during altered $\mathrm{K}^{+}$intake also modulate NCC abundance and phosphorylation by the modulation of the WNK-SPAK/OSR1 pathway [7]. To study the contribution of cullins in mediating the $\mathrm{K}^{+}$effects on NCC independent of other systemic factors, we used our extensively characterized ex vivo renal tubule preparations $[24,43,44]$ and incubated them in different concentrations of $\mathrm{K}^{+}(2.5,3.5$, or $6 \mathrm{mM})$ for $30 \mathrm{~min}$ or $24 \mathrm{~h}$ (Figure 4). After $30 \mathrm{~min}$, compared with $3.5 \mathrm{mM} \mathrm{K}{ }^{+}$, pT58NCC and phosphorylated SPAK levels were significantly increased and decreased after incubation in low or high $\mathrm{K}^{+}$media, respectively (Figure $4 \mathrm{~A}, \mathrm{~B}$ ). These changes occurred without significant differences in total protein abundances of NCC and SPAK (Figure 4A,B). Similar effects on pT58NCC and phosphorylated SPAK were observed after $24 \mathrm{~h}$ incubation (Figure 4C,D). After $24 \mathrm{~h}$, a significant difference in total NCC was also detected between tubules incubated in $2.5 \mathrm{mM}$ and $6 \mathrm{mM} \mathrm{K}^{+}$. Despite these differences in NCC and SPAK levels, no significant differences were observed in the total abundance of Cul1, 3, 4, and 5 or in their n-Cul/Cul ratio at the time points examined (Supplementary Figure S1).

\subsection{Pharmacological Inhibition of Cullin Activity Ex Vivo Increases NCC Phosphorylation}

In ex vivo isolated tubules, the neddylation status (activity) of Cul1, 3, 4, and 5 under control conditions was different, suggesting that they have different basal activities and capacities for activation or inhibition (Supplementary Figure S2). However, treatment of tubules with MLN4924, a pan-cullin inhibitor that prevents cullin activation through inhibition of NAE [45], significantly decreased the neddylation state of Cul1, 3, 4, and 5 within $1 \mathrm{~h}$, effects that remained stable over a $4 \mathrm{~h}$ period (Figure 5A,B). This occurred without changes in total cullin abundance (Supplementary Figure S3). Treatment with MLN4924 significantly increased SPAK and NCC phosphorylation compared with the vehicle-treated groups, with phosphorylation levels increasing in a time-dependent manner (Figure 5A,B). These changes in phosphorylation occurred without significant changes in total protein abundances.

To further investigate whether the effects of cullins on NCC are only via the alteration of the WNK-SPAK pathway, isolated ex vivo renal tubules were incubated with the vehicle or the general WNK inhibitor (stock2s) for $1 \mathrm{~h}$, followed by $2 \mathrm{~h}$ incubation in MLN4924 with/without WNK inhibition. As observed previously (Figure 5), $2 \mathrm{~h}$ treatment with MLN4924 significantly increased SPAK and NCC phosphorylation compared with the vehicle-treated groups (Figure 6). However, in the presence of stock $2 \mathrm{~s}$ the effects of MLN4924 on SPAK and NCC phosphorylation were completely abolished (Figure 6).

\subsection{The Effects of $\mathrm{K}^{+}$on NCC Are Attenuated during Long-Term Cullin Inhibition}

To investigate the ability of $\mathrm{K}^{+}$to modulate NCC in the absence of cullin activity, isolated renal tubules were incubated in different concentrations of $\mathrm{K}^{+}(2.5,3.5$, or $6 \mathrm{mM})$ for $30 \mathrm{~min}$ or $24 \mathrm{~h}$ in the presence or absence of MLN4924. MLN4924 increased the levels of NCC and SPAK phosphorylation without changes to the total protein abundance under all extracellular $\mathrm{K}^{+}$conditions (Supplementary Figure S4). As observed earlier (Figure 4), when compared with tubules incubated in $3.5 \mathrm{mM} \mathrm{K}^{+}$, incubation with $2.5 \mathrm{mM} \mathrm{K}^{+}$for 30 min significantly increased the phosphorylation levels of SPAK and NCC, whereas levels were decreased in $6 \mathrm{mM} \mathrm{K}^{+}$(Figure 7A,B). In the presence of MLN4924, phosphorylation levels of SPAK and NCC were not significantly increased after $30 \mathrm{~min}$ incubation in $2.5 \mathrm{mM}$ relative to $3.5 \mathrm{mM} \mathrm{K}^{+}$, potentially because $\mathrm{WNK}$ and SPAK are already maximally active in the presence of MLN4924 (see Section 4). When tubules were incubated in $6 \mathrm{mM}$ $\mathrm{K}^{+}$, SPAK and NCC phosphorylation were still significantly decreased (Figure 7A,B). No significant differences were observed in total protein abundances under any of the conditions. In contrast, after incubation of tubules for $24 \mathrm{~h}$ in $2.5 \mathrm{mM} \mathrm{K}{ }^{+}$, the significant changes in total and pT58NCC levels (relative to $3.5 \mathrm{mM} \mathrm{K}^{+}$) were absent in the presence of MLN4924 (Figure 8A,B). A significant reduction in total NCC was still observed when tubules were incubated in $6 \mathrm{mM} \mathrm{K}^{+}$and MLN4924, but the change in phosphorylated NCC 
was attenuated, as emphasized by the lack of change in the phosphorylated-NCC-to-totalNCC ratio (like in CUL3-Het/ $\Delta 9$ mice) (Figure $8 \mathrm{~A}, \mathrm{~B}$ ).

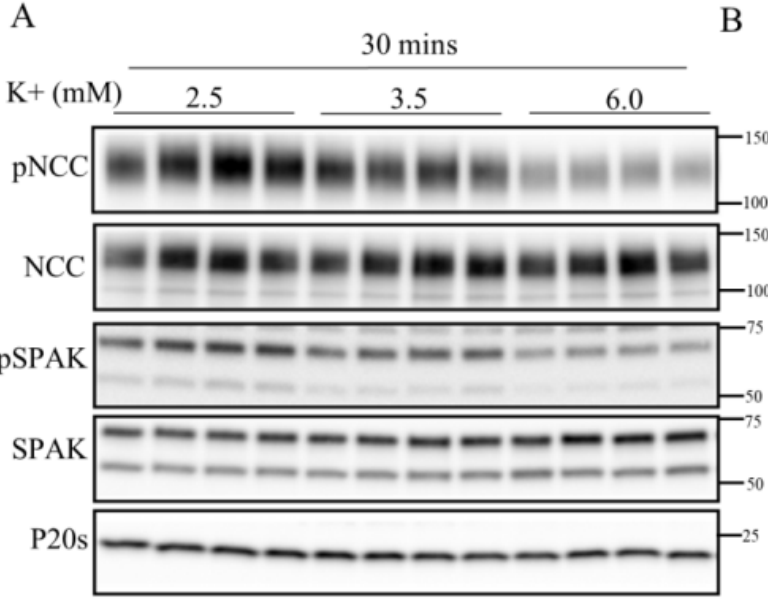

D

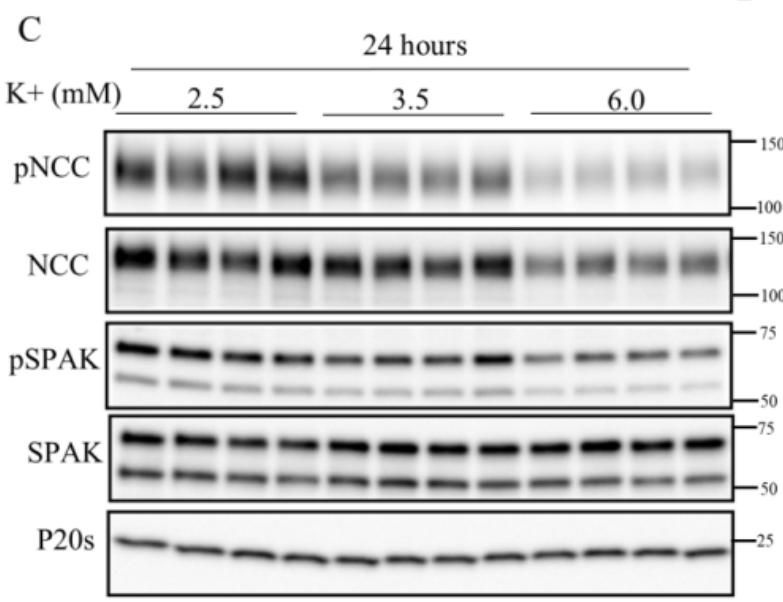

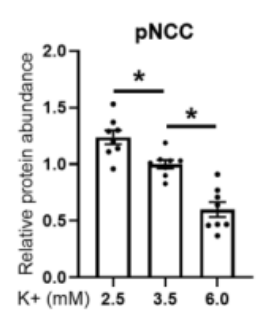
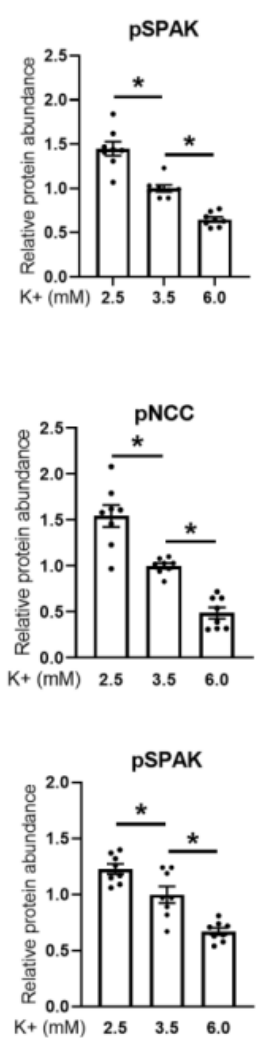

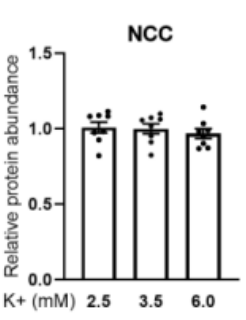

SPAK
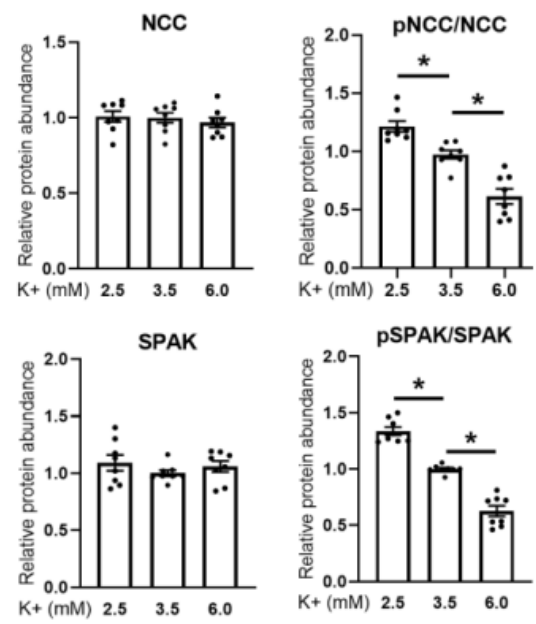
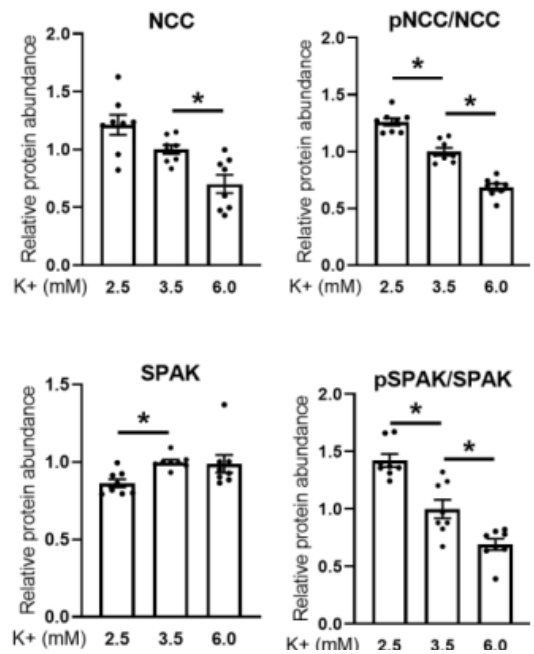

Figure 4. Extracellular $\mathrm{K}^{+}$concentration regulates NCC phosphorylation in isolated renal tubules. (A) Representative immunoblots of pNCC, NCC, pSPAK, SPAK, and P20s in isolated renal tubules that were incubated in the media containing either $2.5,3.5$, or $6 \mathrm{mM} \mathrm{K}^{+}$for 30 min ex vivo. Molecular weight markers $(\mathrm{kDa})$ are shown on the right. (B) Summarized relative protein abundance data. (C) Representative immunoblots of pNCC, NCC, pSPAK, SPAK, and P20s in isolated renal tubules that were incubated in the media containing either $2.5,3.5$, or $6 \mathrm{mM} \mathrm{K}^{+}$for $24 \mathrm{~h}$ ex vivo and (D) summarized relative protein abundance data. In panels with graphs, each dot represents value from an individual well of independent tubules and each bar represents mean \pm SEM obtained from two independent experiments $(n=8)$. ${ }^{*}$ indicates $p<0.05$ relative to $3.5 \mathrm{mM}$ condition. 
A

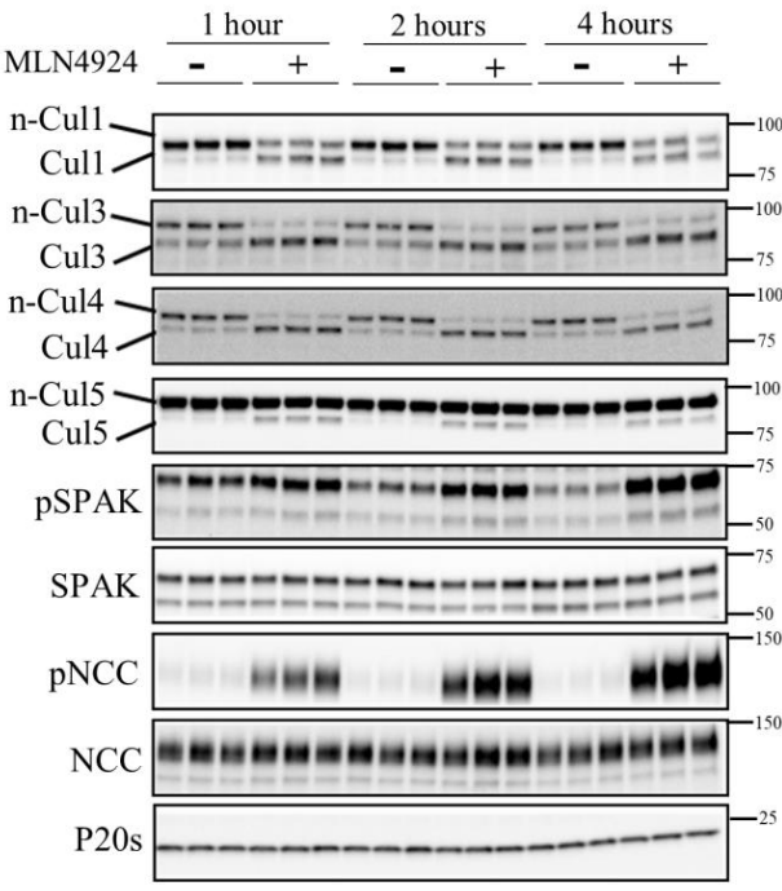

B
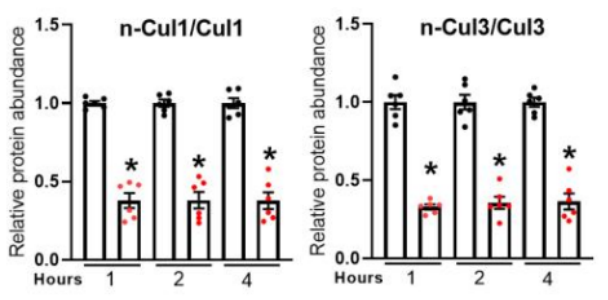

- Vehicle

- MLN4924
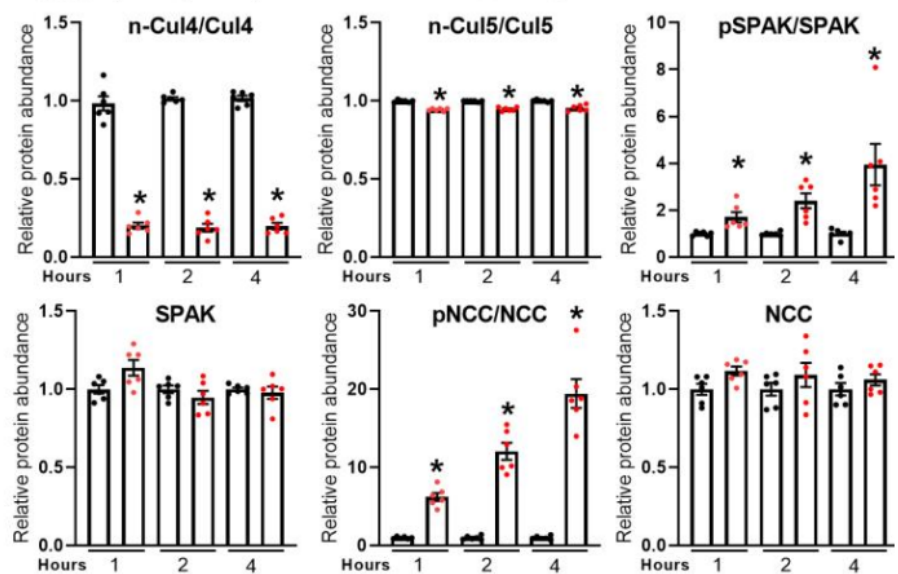

Figure 5. Pharmacological inhibition of cullin neddylation increases NCC phosphorylation in isolated renal tubules ex vivo. (A) Representative immunoblots of Cul1, Cul3, Cul4, Cul5, pSPAK, SPAK, pNCC, NCC, and P20s in isolated renal tubules that were incubated with either vehicle or the cullin inhibitor (MLN4924; $0.5 \mathrm{uM}$ ) for various time points (1, 2, or $4 \mathrm{~h}$ ) ex vivo. Molecular weight markers $(\mathrm{kDa})$ are shown on the right. (B) Summarized relative protein abundance data. Each dot represents value from an individual well of independent tubules and each bar represents mean \pm SEM obtained from two independent experiments $(n=6) .{ }^{*}$ indicates $p<0.05$ relative to $3.5 \mathrm{mM}$ condition.

A

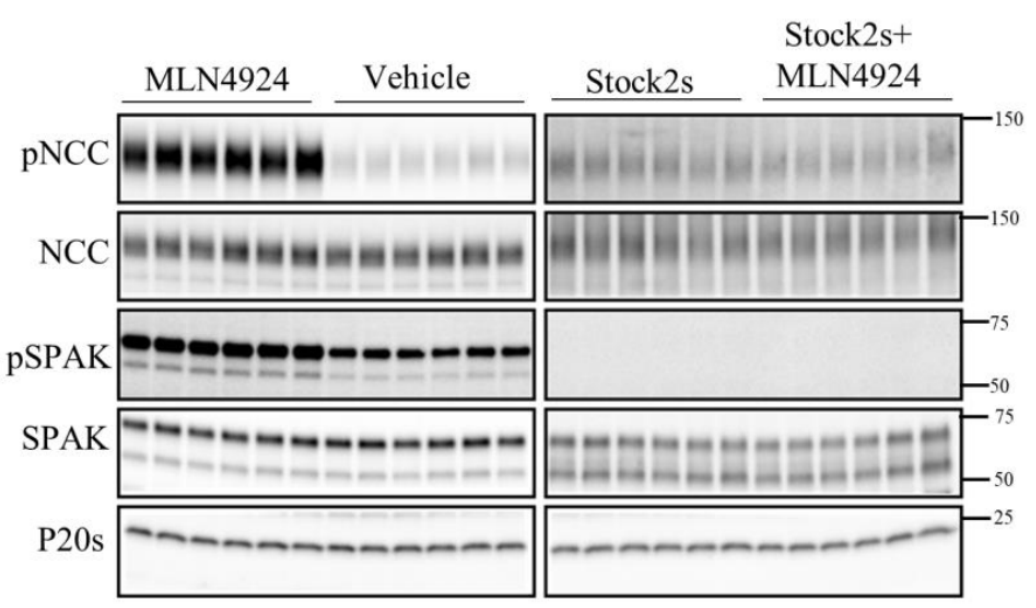

B

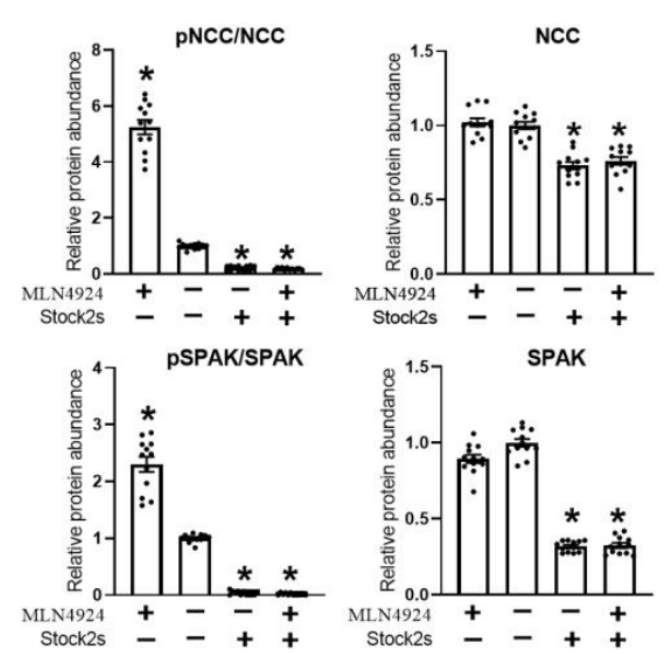

Figure 6. MLN4924 alters NCC phosphorylation via the WNK-SPAK pathway. (A) Representative immunoblots of pNCC, NCC, pSPAK, SPAK, and P20s in isolated renal tubules that were incubated with either the cullin inhibitor (MLN4924), vehicle, WNK inhibitor (Stock2s), or both MLN4924 and the WNK inhibitor. Molecular weight markers (kDa) are shown on the right. (B) Summarized relative protein abundance data. Each dot represents value from an individual well of independent tubules and each bar represents mean \pm SEM obtained from two independent experiments $(n=12)$. ${ }^{*}$ indicates $p<0.05$ relative to vehicle. 

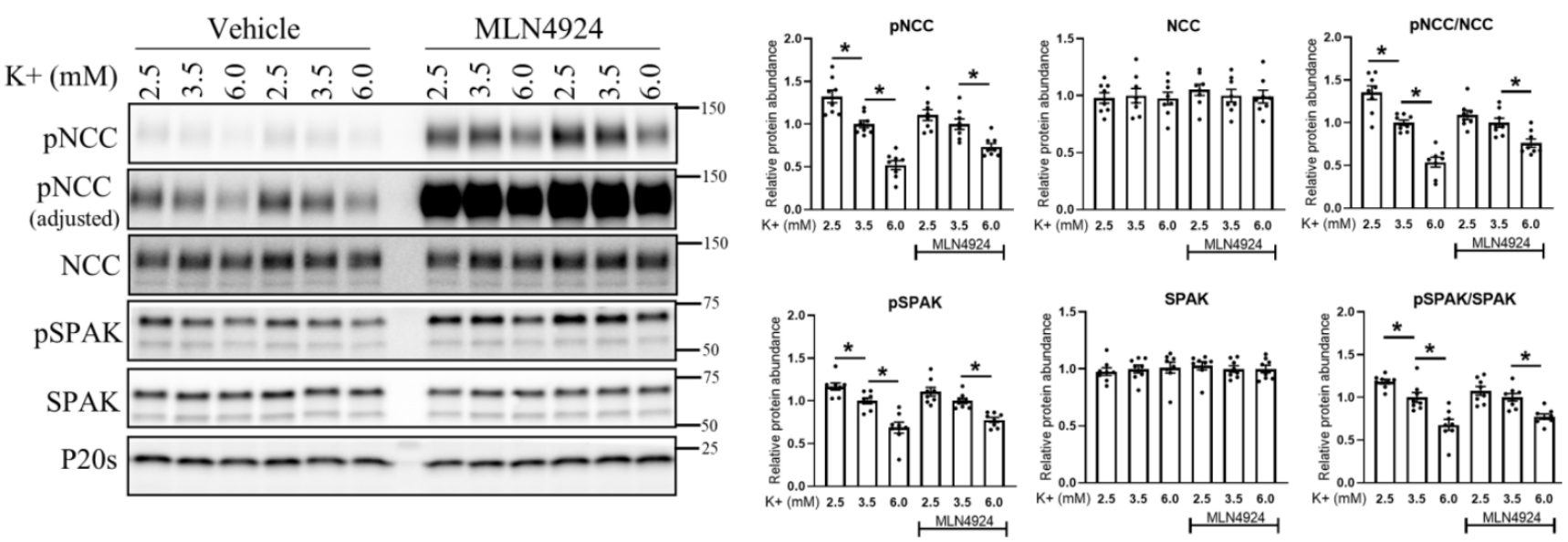

Figure 7. Short-term increase in NCC phosphorylation in response to lower extracellular $\mathrm{K}^{+}$is absent in the presence of MLN4924 in isolated renal tubules ex vivo. (A) Representative immunoblots of pNCC, NCC, pSPAK, SPAK, and P20s in isolated renal tubules that were incubated in the media containing different $\mathrm{K}^{+}$concentrations $\left(2.5,3.5\right.$, or $\left.6 \mathrm{mM} \mathrm{K}^{+}\right)$in the presence of either the vehicle or cullin inhibitor (MLN4924; $0.5 \mathrm{uM}$ ) for 30 min ex vivo. Molecular weight markers (kDa) are shown on the right. (B) Summarized relative protein abundance data. Each dot represents value from an individual well of independent tubules and each bar represents mean $\pm \mathrm{SEM}$ obtained from two independent experiments $(n=8)$. ${ }^{*}$ indicates $p<0.05$ relative to the $3.5 \mathrm{mM} \mathrm{K}^{+}$group.

A

\begin{tabular}{|c|c|c|c|c|c|c|}
\hline \multirow[b]{2}{*}{$\mathrm{K}+(\mathrm{mV}$} & \multicolumn{3}{|c|}{ Vehicle } & \multicolumn{3}{|c|}{ MLN4924 } \\
\hline & 1) 2.5 & 3.5 & 6.0 & 2.5 & 3.5 & 6.0 \\
\hline $\mathrm{pNCC}$ & \multicolumn{3}{|c|}{ 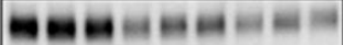 } & \multicolumn{3}{|c|}{ 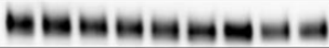 } \\
\hline $\mathrm{NCC}$ & $\theta=0$ & $\mathbf{a t}$ & a & $\Leftrightarrow \in$ & $6=$ & 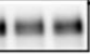 \\
\hline
\end{tabular}

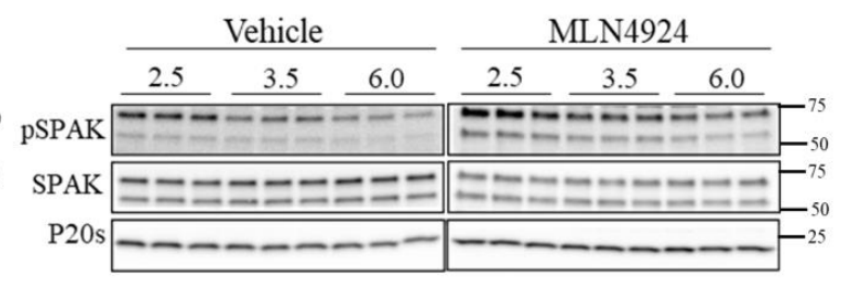

B

B pNCC
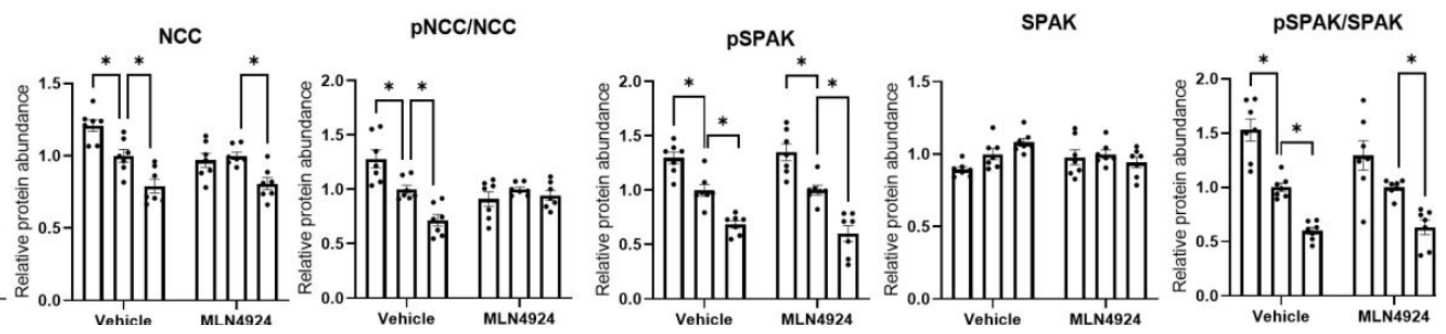

Figure 8. Long-term lower extracellular $\mathrm{K}^{+}$fails to induce NCC phosphorylation and abundance in the presence of MLN4924 in isolated renal tubules ex vivo. (A) Representative immunoblots of pNCC, NCC, pSPAK, SPAK, and P20s in isolated renal tubules that were incubated in the media containing different $\mathrm{K}^{+}$concentrations $\left(2.5,3.5\right.$, or $\left.6 \mathrm{mM} \mathrm{K}^{+}\right)$in the presence of either the vehicle or cullin inhibitor (MLN4924; $0.5 \mathrm{uM}$ ) for $24 \mathrm{~h}$ ex vivo. Molecular weight markers (kDa) are shown on the right. (B) Summarized relative protein abundance data. Each dot represents value from an individual well of independent tubules and each bar represents mean \pm SEM obtained from two independent experiments $(n=6)$. ${ }^{*}$ indicates $p<0.05$ relative to $3.5 \mathrm{mM} \mathrm{K}^{+}$in their respective group.

We subsequently investigated whether the absence of lower extracellular $\mathrm{K}^{+}$effects on NCC expression in the presence of MLN4924 is due to altered expression of the basolateral heterodimeric $\mathrm{K}^{+}$channel Kir 4.1/Kir 5.1. Relative to $3.5 \mathrm{mM}$, no changes in Kir 5.1 protein abundance were observed in isolated renal tubules incubated in 2.5 or $6 \mathrm{mM} \mathrm{K}^{+}$for $24 \mathrm{~h}$ (Supplementary Figure S5). Kir 4.1 protein abundance remained similar when tubules were 
incubated in $2.5 \mathrm{mM} \mathrm{K}^{+}$and $3.5 \mathrm{mM} \mathrm{K}^{+}$(Supplementary Figure S5), but it was significantly decreased in tubules incubated in $6 \mathrm{mM} \mathrm{K}^{+}$. However, this decrease in expression was also observed in the presence of MLN4924 (Supplementary Figure S5).

\section{Discussion}

Reduced dietary $\mathrm{K}^{+}$intake is often associated with increased NCC activity and higher $\mathrm{BP}[2,7,46-49]$, whereas an increase in dietary $\mathrm{K}^{+}$intake is usually associated with lower NCC activity and lower BP [2,3,50]. Dietary changes in $\mathrm{K}^{+}$supplementation in mice alters WNK4 phosphorylation [7,51], and WNK4-/- mice do not increase NCC abundance after a low $\mathrm{K}^{+}$diet [52], suggesting that $\mathrm{K}^{+}$modulates NCC activity via alterations in the activity of WNK kinases. This alteration in WNK kinase activity is mediated, at least in part, through alterations in the activity of the basolateral $\mathrm{K}^{+}$channels Kir 4.1 and Kir 5.1 (forming a Kir 4.1/5.1 heterodimer) and alterations in the intracellular concentration of $\mathrm{Cl}^{-}$ ([Cl- $]$ i) $[7,13,53,54]$. Supporting this, the inhibitory effects of a high $\mathrm{K}^{+}$diet on NCC phosphorylation and abundance are greatly diminished in Kir4.1 or Kir5.1 knockout mice [14,53], and the effects of acute $\mathrm{K}^{+}$loading to reduce NCC phosphorylation are not observed in $\mathrm{Cl}^{-}$-insensitive WNK4 mice [55]. In addition to decreasing WNK4 phosphorylation, $\mathrm{K}^{+}$ supplementation reduces WNK4 abundance [7]. The Cul3 substrate adapter KLHL3 is important in this mechanism, with $\mathrm{K}^{+}$-dependent alterations in KLHL3 phosphorylation changing its ability to bind and degrade WNK4 [16,56,57].

Despite this body of evidence that alterations in $\mathrm{K}^{+}$intake alter the activity and stability of WNK kinases [16], limited information exists on how $\mathrm{K}^{+}$modulates the abundance or activity of cullins, and whether inhibition of cullin activity alters $\mathrm{K}^{+}$-mediated effects on NCC. In an attempt to address this knowledge gap, here we asked three questions: (1) Do long-term alterations in dietary $\mathrm{K}^{+}$intake change cullin abundance or their neddylation status? (2) Are short- or long-term $\mathrm{K}^{+}$-dependent changes in NCC abundance or phosphorylation independent of systemic hormones mediated by alterations in cullin abundance or activity? (3) Are the effects of a long-term high dietary $\mathrm{K}^{+}$intake on NCC altered in a mouse model of FHHt. Our results show that in mice fed various $\mathrm{K}^{+}$diets, the neddylation levels of renal Cul1, 3, 4, and 5 are negatively correlated with pNCC and NCC expression. Furthermore, the $\mathrm{K}^{+}$inhibitory effects on NCC phosphorylation in the long term are attenuated in CUL3-Het/ $\Delta 9$ mice or in the presence of MLN4924 (neddylation inhibitor) in isolated renal tubules. Together our study indicates that $\mathrm{Cul} 3$ and potentially other cullin family members are important for modulating the overall response of the DCT to altered extracellular $\mathrm{K}^{+}$and ultimately NCC activity (summarized in Figure 9).

In kidney samples from mice receiving $0 \%, 1 \%$, or $5 \% \mathrm{~K}^{+}$diet for 2 weeks, we observed progressively less NCC phosphorylation and abundance as dietary $\mathrm{K}^{+}$intake increased (Figure 1). These changes occurred without major differences in the total abundance of Cul1, 3, 4, and 5, and only a small change in the abundance of Cul2 (Figure 1). In contrast, the neddylation status of Cul1, 3, 4, and 5 were increased as dietary $\mathrm{K}^{+}$intake increased, which inversely correlated with phosphorylated and total NCC levels (Figure 2). Together, this suggests that increased dietary $\mathrm{K}^{+}$intake increases cullin activity, and this is associated with less NCC activity. As no significant changes in cullin neddylation were observed after incubating isolated renal tubules in different concentrations of $\mathrm{K}^{+}$for $30 \mathrm{~min}$ or $24 \mathrm{~h}$, systemic factors such as increased aldosterone may be mediating the altered cullin neddylation status observed in vivo, or longer periods of $\mathrm{K}^{+}$exposure are required. A question that remains unanswered is, how does the altered dietary intake alter cullin neddylation? We did not observe a difference in the abundance of the NEDD8 activating enzyme, but in principle, altered abundance/activity of one or more components involved in the cullin neddylation/deneddylation pathway (CAND1, E1, E2 ligase, or COP9 signalosome) or components of the Cullin E3-ligase complex (E2 ligase and substrate receptors) could alter cullin activity. Interestingly, the NEDD8 E3 ligase DCN-like protein 4 (DCNL4) was recently identified as a $\mathrm{K}^{+}$-regulated protein modulating SPAK activity in kidney intercalated cells [58], but whether similar mechanisms occur in the DCT is unknown. 


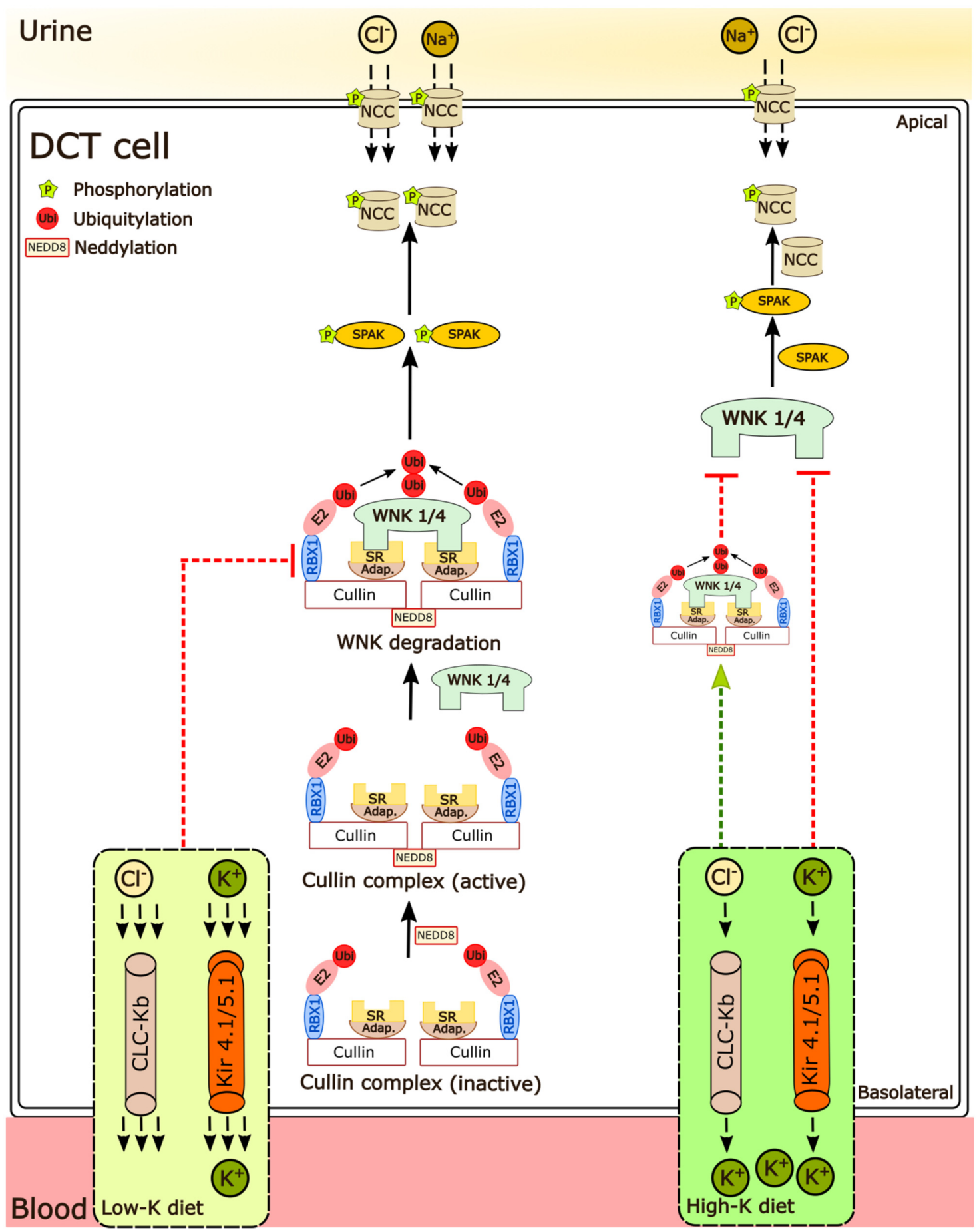

Figure 9. Regulation of NCC phosphorylation under different $\mathrm{K}^{+}$conditions. Cullins are a family of E3 ligases that are activated through neddylation, a post-translational modification in which the ubiquitin-like modifier NEDD8 is covalently attached to the target protein. Active cullin complexes can bind to their substrate, resulting in target ubiquitylation and subsequent degradation. Higher extracellular $\mathrm{K}^{+}$concentrations limit NCC phosphorylation, but this effect is attenuated in the absence of active cullins, suggesting that the responses on NCC are partly dependent on cullin activity. A lower extracellular $\mathrm{K}^{+}$concentration increases SPAK and NCC phosphorylation, but not as much in the absence of active cullins. Although this suggests that the effects of low extracellular $\mathrm{K}^{+}$on NCC phosphorylation are fully dependent of cullin activity, more likely is that in the absence of cullin activity WNK, SPAK, and NCC phosphorylation are already maximized and no further increases are possible. SR-substrate receptor; Adap.-adaptor protein. 
Inhibition of cullin neddylation ex vivo using MLN4924 potently increased SPAK and NCC phosphorylation within $1 \mathrm{~h}$, an effect sustained over a $4 \mathrm{~h}$ period (Figure 5 ). These changes were likely driven by increased WNK activity, as MLN4924 had no effect during WNK inhibition (Figure 6). In the presence of MLN4924, no increases in NCC abundance $(24 \mathrm{~h})$ or phosphorylation (30 min and $24 \mathrm{~h}$ ) were observed in ex vivo tubules incubated in low $\mathrm{K}^{+}$media (Figures 7 and 8 ). Although this lack of response may suggest that $\mathrm{K}^{+}$-driven increases in NCC are dependent on cullin activity, the most likely explanation is that in the presence of MLN4924, SPAK and NCC phosphorylation are already at a maximum and no further increases are possible. These results are in line with what is observed in $\mathrm{Cl}^{-}$-insensitive WNK4 mice, where dietary $\mathrm{K}^{+}$restriction did not further in-crease NCC phosphorylation above the already-raised levels [55]. Together the results support the fact that activation of the Kir 4.1/5.1-WNK-SPAK pathway is the major mechanism for the upregulation of NCC by dietary $\mathrm{K}^{+}$restriction [11-15]. However, as there is experimental evidence that cullins can interact with and regulate various phosphatases, $\mathrm{K}^{+}$-mediated changes in protein phosphatase activity during dietary $\mathrm{K}^{+}$restriction warrants further investigation [59-63].

After $30 \mathrm{~min}^{\prime}$ incubation of tubules in higher extracellular $\mathrm{K}^{+}$(from 3.5 to $6 \mathrm{mM}$ ), NCC phosphorylation was still reduced despite the presence of MLN4924, suggesting that acute reductions in NCC phosphorylation are independent of cullin and potentially WNK activity. This could suggest that in the short term, the "on switch" for NCC and SPAK phosphorylation (i.e., WNK kinase phosphorylation) does not need to be "turned off" for the high $\mathrm{K}^{+}$-mediated effects to occur. However, acute effects of potassium on NCC phosphorylation are absent in $\mathrm{Cl}^{-}$-insensitive WNK4 mice and in SPAK knockout mice $[55,64]$, suggesting that in vivo there is a complex interplay between plasma $\mathrm{K}^{+}$, systemic factors, and NCC that is absent in the ex vivo tubules. Such an idea is supported by acute $\mathrm{K}^{+}$loading only decreasing NCC phosphorylation in mice that were prior $\mathrm{K}^{+}$restricted for 1 day, but not in mice that were chronically $\mathrm{K}^{+}$-restricted for 5 days [64].

In contrast, in tubules the long-term effects of high $\mathrm{K}^{+}$on NCC phosphorylation were attenuated in the presence of MLN4924, fitting well with studies in the FHHt CUL3-Het/ $\Delta 9$ mice, where the ability of a high dietary $\mathrm{K}^{+}$intake to reduce NCC phosphorylation was also limited (Figure 3). Thus, when WNK4 activity is high, chronic effects of high $\mathrm{K}^{+}$on NCC phosphorylation are reduced, but not prevented, suggesting that NCC dephosphorylation is also important. This is supported by studies in $\mathrm{Cl}^{-}$-insensitive WNK4 mice [55], where the chronic effects of potassium loading on NCC phosphorylation still occur. Previous studies support the idea that there are alternative time-dependent mechanisms at play on NCC during $\mathrm{K}^{+}$loading, with early effects being driven by reductions in the activity of the WNK-SPAK pathway, whereas later effects may be driven by alterations in the WNK-SPAK activity but also by changes in NCC dephosphorylation. Further studies are required to examine this possibility, but unfortunately, the phosphatase responsible for NCC dephosphorylation subsequent to a high $\mathrm{K}^{+}$load is still unclear with inconsistent results using PP1, PP2, or PP4 phosphatase inhibitors [47,64-66].

In conclusion, our results indicate that chronic $\mathrm{K}^{+}$loading effects on NCC partially depend on the actions of one or more cullins. Deciphering the importance of individual members and how their actions converge and combine with other regulatory mechanisms to exert overall effects on NCC will require the generation and phenotyping of mice where individual cullins are deleted only in the DCT.

Supplementary Materials: The following are available online at https: / www.mdpi.com/article / 10.3390/cells11010095/s1, Consists of five supplemental figures. Supplementary Figure S1. Incubation of ex vivo renal tubule preparations in media with various concentrations of $\mathrm{K}+$ has no significant effect on total abundance of Cul 1, 3, 4 and 5 or in their n-Cul/Cul ratio; Supplementary Figure S2. The basal neddylation status (activity) of Cul 1, 3, 4 and 5 are different; Supplementary Figure S3. Treatment of isolated renal tubules ex vivo with MLN4924 had no significant effect on the total abundance of cullins; Supplementary Figure S4. MLN4924 effects on NCC and SPAK phosphorylation is 
intact under different extracellu-lar K+ concentration; Supplementary Figure S5. Inhibition of cullins does not alter $\mathrm{K}+$ effects on the $\mathrm{K}+$ channels Kir 4.1 and Kir 5.1

Author Contributions: R.A.F. conceived the study. S.K.M., R.L., S.B.P., M.Z.F., J.A.M., D.H.E. and R.A.F. acquired, analyzed, and interpreted data. S.K.M. and R.A.F. drafted the manuscript. S.K.M., R.L., S.B.P., M.Z.F., J.A.M., D.H.E. and R.A.F. approved the final version of the manuscript and agree to be accountable for all aspects of the work. All authors have read and agreed to the published version of the manuscript.

Funding: The project was funded by the Leducq Foundation (17CVD05), Novo Nordisk Foundation (NNF21OC0067647, NNF17OC0029724, NNF19OC0058439), Independent Research Fund Denmark, and National Institute of Diabetes and Digestive and Kidney Diseases grants DK098141 (to J.A.M.) and DK51496 and DK054983 (to D.H.E.).

Institutional Review Board Statement: The animal study protocols were approved by the Danish Ministry of Justice (Dyreforsøgstilsynet) or the Oregon Health and Science University Institutional Animal Care and Use Committee (protocol IP00286).

Acknowledgments: We would like to thank Tina Drejer for her technical assistance.

Conflicts of Interest: The authors declare no conflict of interest.

\section{References}

1. Egan, B.M.; Kjeldsen, S.E.; Grassi, G.; Esler, M.; Mancia, G. The global burden of hypertension exceeds 1.4 billion people: Should a systolic blood pressure target below 130 become the universal standard? J. Hypertens. 2019, 37, 1148-1153. [CrossRef]

2. Mente, A.; O’Donnell, M.J.; Rangarajan, S.; McQueen, M.J.; Poirier, P.; Wielgosz, A.; Morrison, H.; Li, W.; Wang, X.; Di, C.; et al. Association of Urinary Sodium and Potassium Excretion with Blood Pressure. N. Engl. J. Med. 2014, 371, 601-611. [CrossRef]

3. O'Donnell, M.; Mente, A.; Rangarajan, S.; McQueen, M.J.; Wang, X.; Liu, L.; Yan, H.; Lee, S.F.; Mony, P.; Devanath, A.; et al. Urinary sodium and potassium excretion, mortality, and cardiovascular events. N. Engl. J. Med. 2014, 371, 612-623. [CrossRef] [PubMed]

4. Lang, F.; Capasso, G.; Schwab, M.; Waldegger, S. Renal tubular transport and the genetic basis of hypertensive disease. Clin. Exp. Nephrol. 2005, 9, 91-99. [CrossRef]

5. Simon, D.B.; Nelson-Williams, C.; Bia, M.J.; Ellison, D.; Karet, F.E.; Molina, A.M.; Vaara, I.; Iwata, F.; Cushner, H.M.; Koolen, M.; et al. Gitelman's variant of Bartter's syndrome, inherited hypokalaemic alkalosis, is caused by mutations in the thiazide-sensitive Na-Cl cotransporter. Nat. Genet. 1996, 12, 24-30. [CrossRef] [PubMed]

6. Vitzthum, H.; Seniuk, A.; Schulte, L.H.; Müller, M.L.; Hetz, H.; Ehmke, H. Functional coupling of renal K + and Na + handling causes high blood pressure in $\mathrm{Na}+$ replete mice. J. Physiol. 2014, 592, 1139-1157. [CrossRef]

7. Terker, A.S.; Zhang, C.; McCormick, J.; Lazelle, R.A.; Zhang, C.; Meermeier, N.P.; Siler, D.A.; Park, H.J.; Fu, Y.; Cohen, D.M.; et al. Potassium Modulates Electrolyte Balance and Blood Pressure through Effects on Distal Cell Voltage and Chloride. Cell Metab. 2015, 21, 39-50. [CrossRef] [PubMed]

8. Wilson, F.H.; Disse-Nicodème, S.; Choate, K.A.; Ishikawa, K.; Nelson-Williams, C.; Desitter, I.; Gunel, M.; Milford, D.V.; Lipkin, G.W.; Achard, J.-M.; et al. Human Hypertension Caused by Mutations in WNK Kinases. Science 2001, 293, 1107-1112. [CrossRef] [PubMed]

9. McCormick, J.A.; Ellison, D.H. Distal convoluted tubule. Compr. Physiol. 2015, 5, 45-98.

10. Boyden, L.M.; Choi, M.; Choate, K.A.; Nelson-Williams, C.J.; Farhi, A.; Toka, H.R.; Tikhonova, I.R.; Bjornson, R.; Mane, S.M.; Colussi, G.; et al. Mutations in kelch-like 3 and cullin 3 cause hypertension and electrolyte abnormalities. Nature 2012, 482, 98-102. [CrossRef] [PubMed]

11. Piala, A.T.; Moon, T.M.; Akella, R.; He, H.; Cobb, M.H.; Goldsmith, E.J. Chloride Sensing by WNK1 Involves Inhibition of Autophosphorylation. Sci. Signal. 2014, 7, ra41. [CrossRef]

12. Bazúa-Valenti, S.; Chávez-Canales, M.; Rojas, L.; González-Rodríguez, X.; Vázquez, N.; Rodríguez-Gama, A.; Argaiz, E.; Melo, Z.; Plata, C.; Ellison, D.; et al. The Effect of WNK4 on the Na+-Cl-Cotransporter Is Modulated by Intracellular Chloride. J. Am. Soc. Nephrol. 2014, 26, 1781-1786. [CrossRef]

13. Cuevas, C.; Su, X.-T.; Wang, M.-X.; Terker, A.S.; Lin, D.-H.; McCormick, J.; Yang, C.-L.; Ellison, D.H.; Wang, W.-H. Potassium Sensing by Renal Distal Tubules Requires Kir4.1. J. Am. Soc. Nephrol. 2017, 28, 1814-1825. [CrossRef]

14. Wu, P.; Gao, Z.-X.; Zhang, D.-D.; Su, X.-T.; Wang, W.-H.; Lin, D.-H. Deletion of Kir5.1 Impairs Renal Ability to Excrete Potassium during Increased Dietary Potassium Intake. J. Am. Soc. Nephrol. 2019, 30, 1425-1438. [CrossRef]

15. Hoorn, E.J.; Gritter, M.; Cuevas, C.A.; Fenton, R.A. Regulation of the Renal NaCl Cotransporter and Its Role in Potassium Homeostasis. Physiol. Rev. 2020, 100, 321-356. [CrossRef]

16. Ishizawa, K.; Xu, N.; Loffing, J.; Lifton, R.P.; Fujita, T.; Uchida, S.; Shibata, S. Potassium depletion stimulates Na-Cl cotransporter via phosphorylation and inactivation of the ubiquitin ligase Kelch-like 3. Biochem. Biophys. Res. Commun. 2016, 480, 745-751. [CrossRef] [PubMed] 
17. Lee, J.; Zhou, P. Cullins and cancer. Genes Cancer 2010, 1, 690-699. [CrossRef] [PubMed]

18. Enchev, R.I.; Schulman, B.; Peter, M. Protein neddylation: Beyond cullin-RING ligases. Nat. Rev. Mol. Cell Biol. 2015, 16, 30-44. [CrossRef] [PubMed]

19. Merlet, J.; Burger, J.; Gomes, J.-E.; Pintard, L. Regulation of cullin-RING E3 ubiquitin-ligases by neddylation and dimerization. Cell. Mol. Life Sci. 2009, 66, 1924-1938. [CrossRef] [PubMed]

20. Gong, L.; Yeh, E.T.H. Identification of the Activating and Conjugating Enzymes of the NEDD8 Conjugation Pathway. J. Biol. Chem. 1999, 274, 12036-12042. [CrossRef] [PubMed]

21. Deshaies, R.J.; Emberley, E.D.; Saha, A. Control of Cullin-Ring Ubiquitin Ligase Activity by Nedd8. Subcell Biochem. 2010, 54, 41-56. [CrossRef]

22. Wei, N.; Serino, G.; Deng, X.-W. The COP9 signalosome: More than a protease. Trends Biochem. Sci. 2008, 33, 592-600. [CrossRef]

23. Schmaler, T.; Dubiel, W. Control of Deneddylation by the COP9 Signalosome. Subcell Biochem. 2010, 54, 57-68. [CrossRef]

24. Kortenoeven, M.L.A.; Cheng, L.; Wu, Q.; Fenton, R.A. An in vivo protein landscape of the mouse DCT during high dietary K+ or low dietary Na+ intake. Am. J. Physiol. Physiol. 2021, 320, F908-F921. [CrossRef]

25. Ferdaus, M.; Miller, L.N.; Agbor, L.N.; Saritas, T.; Singer, J.D.; Sigmund, C.; McCormick, J.A. Mutant Cullin 3 causes familial hyperkalemic hypertension via dominant effects. JCI Insight 2017, 2. [CrossRef] [PubMed]

26. Murali, S.K.; Aroankins, T.S.; Moeller, H.B.; Fenton, R.A. The Deubiquitylase USP4 Interacts with the Water Channel AQP2 to Modulate Its Apical Membrane Accumulation and Cellular Abundance. Cells 2019, 8, 265. [CrossRef] [PubMed]

27. Kortenoeven, M.L.; Esteva-Font, C.; Dimke, H.; Poulsen, S.B.; Murali, S.K.; Fenton, R.A. High dietary potassium causes ubiquitindependent degradation of the kidney sodium-chloride cotransporter. J. Biol. Chem. 2021, 297, 100915. [CrossRef] [PubMed]

28. Pedersen, N.B.; Hofmeister, M.V.; Rosenbaek, L.L.; Nielsen, J.; Fenton, R.A. Vasopressin induces phosphorylation of the thiazidesensitive sodium chloride cotransporter in the distal convoluted tubule. Kidney Int. 2010, 78, 160-169. [CrossRef]

29. Moriguchi, T.; Urushiyama, S.; Hisamoto, N.; Iemura, S.-I.; Uchida, S.; Natsume, T.; Matsumoto, K.; Shibuya, H. WNK1 Regulates Phosphorylation of Cation-Chloride-coupled Cotransporters via the STE20-related Kinases, SPAK and OSR1. J. Biol. Chem. 2005, 280, 42685-42693. [CrossRef]

30. McCormick, J.A.; Nelson, J.H.; Yang, C.L.; Curry, J.N.; Ellison, D.H. Overexpression of the sodium chloride cotransporter is not sufficient to cause familial hyperkalemic hypertension. Hypertension 2011, 58, 888-894. [CrossRef]

31. Wu, K.; Chen, A.; Pan, Z.Q. Conjugation of Nedd8 to CUL1 enhances the ability of the ROC1-CUL1 complex to promote ubiquitin polymerization. J. Biol. Chem. 2000, 275, 32317-32324. [CrossRef]

32. Zhou, W.; Xu, J.; Li, H.; Xu, M.; Chen, Z.; Weihua, Z.; Pan, Z.; Sun, Y. Neddylation E2 UBE2F Promotes the Survival of Lung Cancer Cells by Activating CRL5 to Degrade NOXA via the K11 Linkage. Clin. Cancer Res. 2016, 23, 1104-1116. [CrossRef] [PubMed]

33. Duda, D.M.; Borg, L.A.; Scott, D.C.; Hunt, H.W.; Hammel, M.; Schulman, B.A. Structural Insights into NEDD8 Activation of Cullin-RING Ligases: Conformational Control of Conjugation. Cell 2008, 134, 995-1006. [CrossRef] [PubMed]

34. Saha, A.; Deshaies, R.J. Multimodal Activation of the Ubiquitin Ligase SCF by Nedd8 Conjugation. Mol. Cell 2008, 32, 21-31. [CrossRef] [PubMed]

35. Wang, K.; Reichermeier, K.M.; Liu, X. Quantitative analyses for effects of neddylation on CRL2 VHL substrate ubiquitination and degradation. Protein Sci. 2021, 30, 2338-2345. [CrossRef]

36. Boh, B.K.; Smith, P.G.; Hagen, T. Neddylation-Induced Conformational Control Regulates Cullin RING Ligase Activity In Vivo. J. Mol. Biol. 2011, 409, 136-145. [CrossRef]

37. Ferdaus, M.Z.; McCormick, J.A. The CUL3/KLHL3-WNK-SPAK/OSR1 pathway as a target for antihypertensive therapy. Am. J. Physiol. Ren. Physiol. 2016, 310, F1389-F1396. [CrossRef]

38. McCormick, J.; Yang, C.-L.; Zhang, C.; Davidge, B.; Blankenstein, K.I.; Terker, A.; Yarbrough, B.; Meermeier, N.P.; Park, H.J.; McCully, B.; et al. Hyperkalemic hypertension-associated cullin 3 promotes WNK signaling by degrading KLHL3. J. Clin. Investig. 2014, 124, 4723-4736. [CrossRef]

39. Ferdaus, M.Z.; McCormick, J. Mechanisms and controversies in mutant Cul3-mediated familial hyperkalemic hypertension. Am. J. Physiol. Physiol. 2018, 314, F915-F920. [CrossRef]

40. Vallon, V.; Schroth, J.; Lang, F.; Kuhl, D.; Uchida, S. Expression and phosphorylation of the Na+-Cl- cotransporter NCC in vivo is regulated by dietary salt, potassium, and SGK1. Am. J. Physiol. Ren. Physiol. 2009, 297, F704-F712. [CrossRef]

41. Van Der Lubbe, N.; Lim, C.H.; Fenton, R.A.; Meima, M.E.; Danser, A.H.J.; Zietse, R.; Hoorn, E.J. Angiotensin II induces phosphorylation of the thiazide-sensitive sodium chloride cotransporter independent of aldosterone. Kidney Int. 2011, 79, 66-76. [CrossRef] [PubMed]

42. van der Lubbe, N.; Lim, C.H.; Meima, M.E.; van Veghel, R.; Rosenbaek, L.L.; Mutig, K. Aldosterone does not require angiotensin II to activate NCC through a WNK4-SPAK-dependent pathway. Pflug. Arch. 2012, 463, 853-863. [CrossRef] [PubMed]

43. Poulsen, S.B.; Cheng, L.; Penton, D.; Kortenoeven, M.L.; Matchkov, V.V.; Loffing, J.; Little, R.; Murali, S.K.; Fenton, R.A. Activation of the kidney sodium chloride cotransporter by the beta2-adrenergic receptor agonist salbutamol increases blood pressure. Kidney Int. 2021, 100, 321-335. [CrossRef] [PubMed]

44. Cheng, L.; Poulsen, S.B.; Wu, Q.; Esteva-Font, C.; Olesen, E.T.B.; Peng, L.; Olde, B.; Leeb-Lundberg, L.M.F.; Pisitkun, T.; Rieg, T.; et al. Rapid Aldosterone-Mediated Signaling in the DCT Increases Activity of the Thiazide-Sensitive NaCl Cotransporter. J. Am. Soc. Nephrol. 2019, 30, 1454-1470. [CrossRef] 
45. Brownell, J.E.; Sintchak, M.D.; Gavin, J.M.; Liao, H.; Bruzzese, F.J.; Bump, N.J.; Soucy, T.A.; Milhollen, M.A.; Yang, X.; Burkhardt, A.L.; et al. Substrate-Assisted Inhibition of Ubiquitin-like Protein-Activating Enzymes: The NEDD8 E1 Inhibitor MLN4924 Forms a NEDD8-AMP Mimetic In Situ. Mol. Cell 2010, 37, 102-111. [CrossRef]

46. Sacks, F.M.; Svetkey, L.P.; Vollmer, W.M.; Appel, L.J.; Bray, G.A.; Harsha, D.; Obarzanek, E.; Conlin, P.R.; Miller, E.R.; SimonsMorton, D.G.; et al. Effects on Blood Pressure of Reduced Dietary Sodium and the Dietary Approaches to Stop Hypertension (DASH) Diet. N. Engl. J. Med. 2001, 344, 3-10. [CrossRef]

47. Sorensen, M.V.; Grossmann, S.; Roesinger, M.; Gresko, N.; Todkar, A.P.; Barmettler, G.; Ziegler, U.; Odermatt, A.; Loffing-Cueni, D.; Loffing, J. Rapid dephosphorylation of the renal sodium chloride cotransporter in response to oral potassium intake in mice. Kidney Int. 2013, 83, 811-824. [CrossRef]

48. Rengarajan, S.; Lee, D.H.; Oh, Y.T.; Delpire, E.; Youn, J.H.; McDonough, A.A. Increasing plasma [K+] by intravenous potassium infusion reduces NCC phosphorylation and drives kaliuresis and natriuresis. Am. J. Physiol. Physiol. 2014, 306, F1059-F1068. [CrossRef]

49. Frindt, G.; Palmer, L.G. Effects of dietary K on cell-surface expression of renal ion channels and transporters. Am. J. Physiol. Physiol. 2010, 299, F890-F897. [CrossRef]

50. Akita, S.; Sacks, F.M.; Svetkey, L.P.; Conlin, P.R.; Kimura, G. Effects of the Dietary Approaches to Stop Hypertension (DASH) Diet on the Pressure-Natriuresis Relationship. Hypertension 2003, 42, 8-13. [CrossRef]

51. Terker, A.S.; Zhang, C.; Erspamer, K.J.; Gamba, G.; Yang, C.-L.; Ellison, D.H. Unique chloride-sensing properties of WNK4 permit the distal nephron to modulate potassium homeostasis. Kidney Int. 2016, 89, 127-134. [CrossRef] [PubMed]

52. Takahashi, D.; Mori, T.; Nomura, N.; Khan, M.Z.H.; Araki, Y.; Zeniya, M.; Sohara, E.; Rai, T.; Sasaki, S.; Uchida, S. WNK4 is the major WNK positively regulating NCC in the mouse kidney. Biosci. Rep. 2014, 34, 195-205. [CrossRef] [PubMed]

53. Wang, M.-X.; Cuevas, C.; Su, X.-T.; Wu, P.; Gao, Z.-X.; Lin, D.-H.; McCormick, J.; Yang, C.-L.; Wang, W.-H.; Ellison, D.H. Potassium intake modulates the thiazide-sensitive sodium-chloride cotransporter (NCC) activity via the Kir4.1 potassium channel. Kidney Int. 2018, 93, 893-902. [CrossRef] [PubMed]

54. Su, X.-T.; Klett, N.J.; Sharma, A.; Allen, C.N.; Wang, W.-H.; Yang, C.-L.; Ellison, D.H. Distal convoluted tubule Cl- concentration is modulated via K+ channels and transporters. Am. J. Physiol. Physiol. 2020, 319, F534-F540. [CrossRef]

55. Chen, J.-C.; Lo, Y.-F.; Lin, Y.-W.; Lin, S.-H.; Huang, C.-L.; Cheng, C.-J. WNK4 kinase is a physiological intracellular chloride sensor. Proc. Natl. Acad. Sci. USA 2019, 116, 4502-4507. [CrossRef]

56. Ishizawa, K.; Wang, Q.; Li, J.; Yamazaki, O.; Tamura, Y.; Fujigaki, Y.; Uchida, S.; Lifton, R.P.; Shibata, S. Calcineurin dephosphorylates Kelch-like 3, reversing phosphorylation by angiotensin II and regulating renal electrolyte handling. Proc. Natl. Acad. Sci. USA 2019, 116, 3155-3160. [CrossRef]

57. Shibata, S.; Arroyo, J.P.; Castañeda-Bueno, M.; Puthumana, J.; Zhang, J.; Uchida, S.; Stone, K.L.; Lam, T.T.; Lifton, R.P. Angiotensin II signaling via protein kinase C phosphorylates Kelch-like 3, preventing WNK4 degradation. Proc. Natl. Acad. Sci. USA 2014, 111, 15556-15561. [CrossRef]

58. Nkashama, L.J.; Roy, A.; Carrisoza-Gaytan, R.; Ray, E.C.; Marciszyn, A.; Kleyman, T.R. The Nedd8 Co-E3 DCNL4 is regulated by dietary potassium in renal intercalated cells and promotes WNK kinase degradation via the KLHL3/CUL3 complex. FASEB J. 2018, 32, 747-748. [CrossRef]

59. Yu, C.; Ji, S.-Y.; Sha, Q.-Q.; Sun, Q.-Y.; Fan, H.-Y. CRL4-DCAF1 ubiquitin E3 ligase directs protein phosphatase 2A degradation to control oocyte meiotic maturation. Nat. Commun. 2015, 6, 8017. [CrossRef]

60. Xu, J.; Zhou, J.-Y.; Xu, Z.; Kho, D.-H.; Zhuang, Z.; Raz, A.; Wu, G.S. The role of Cullin3-mediated ubiquitination of the catalytic subunit of PP2A in TRAIL signaling. Cell Cycle 2014, 13, 3750-3758. [CrossRef]

61. Flores-Delgado, G.; Liu, C.W.Y.; Sposto, A.R.; Berndt, N. A Limited Screen for Protein Interactions Reveals New Roles for Protein Phosphatase 1 in Cell Cycle Control and Apoptosis. J. Proteome Res. 2007, 6, 1165-1175. [CrossRef]

62. Li, X.; Liu, J.; Gao, T. $\beta$-TrCP-mediated ubiquitination and degradation of PHLPP1 are negatively regulated by Akt. Mol. Cell. Biol. 2009, 29, 6192-6205. [CrossRef]

63. Dushukyan, N.; Dunn, D.; Sager, R.A.; Woodford, M.; Loiselle, D.R.; Daneshvar, M.; Baker-Williams, A.J.; Chisholm, J.; Truman, A.; Vaughan, C.K.; et al. Phosphorylation and Ubiquitination Regulate Protein Phosphatase 5 Activity and Its Prosurvival Role in Kidney Cancer. Cell Rep. 2017, 21, 1883-1895. [CrossRef] [PubMed]

64. Mukherjee, A.; Yang, C.-L.; McCormick, J.A.; Martz, K.; Sharma, A.; Ellison, D.H. Roles of WNK4 and SPAK in K+-mediated dephosphorylation of the $\mathrm{NaCl}$ cotransporter. Am. J. Physiol. Physiol. 2021, 320, F719-F733. [CrossRef] [PubMed]

65. Shoda, W.; Nomura, N.; Ando, F.; Mori, Y.; Mori, T.; Sohara, E.; Rai, T.; Uchida, S. Calcineurin inhibitors block sodium-chloride cotransporter dephosphorylation in response to high potassium intake. Kidney Int. 2016, 91, 402-411. [CrossRef]

66. Penton, D.; Czogalla, J.; Wengi, A.; Himmerkus, N.; Loffing-Cueni, D.; Carrel, M.; Rajaram, R.D.; Staub, O.; Bleich, M.; Schweda, F.; et al. Extracellular $\mathrm{K}^{+}$rapidly controls $\mathrm{NaCl}$ cotransporter phosphorylation in the native distal convoluted tubule by $\mathrm{Cl}^{-}$-dependent and independent mechanisms. J. Physiol. 2016, 594, 6319-6331. [CrossRef] [PubMed] 